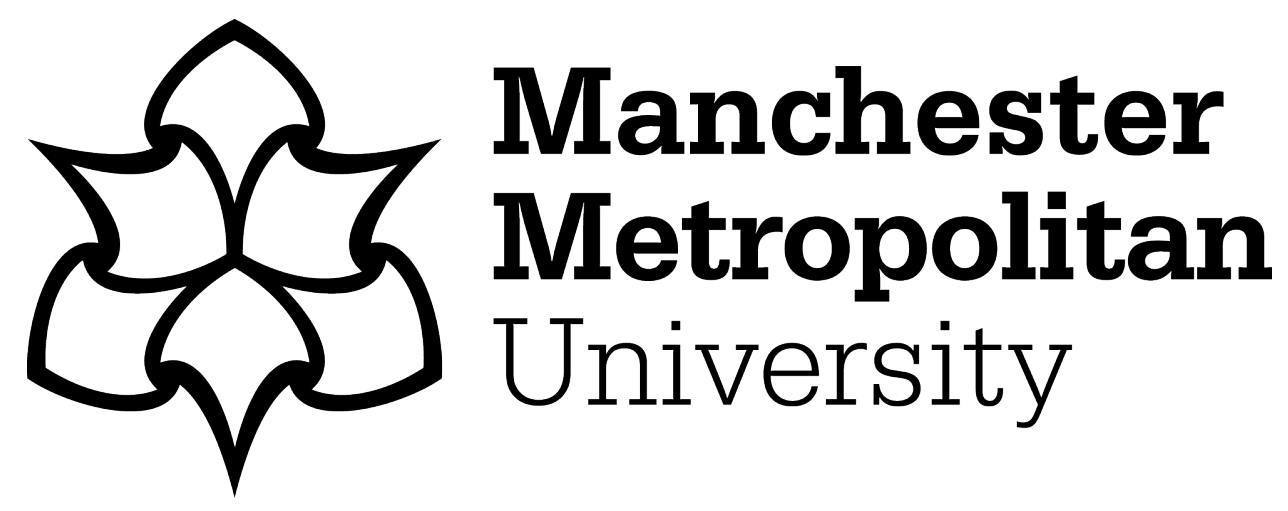

Collins, C, Asouti, E, Grove, M, Kabukcu, C, Bradley, L ORCID logoORCID: https://orcid.org/0000-0003-0833-9351 and Chiverrell, R (2018) Understanding resource choice at the transition from foraging to farming: An application of palaeodistribution modelling to the Neolithic of the Konya Plain, southcentral Anatolia, Turkey. Journal of Archaeological Science, 96. pp. 57-72. ISSN 0305-4403

Downloaded from: https://e-space.mmu.ac.uk/624413/

Version: Accepted Version

Publisher: Elsevier

DOI: https://doi.org/10.1016/j.jas.2018.02.003

Usage rights: Creative Commons: Attribution-Noncommercial-No Derivative Works 4.0

Please cite the published version 
1 Title:

2 Understanding resource choice at the transition from foraging to farming: An

3 application of palaeodistribution modelling to the Neolithic of the Konya Plain, south-central

4 Anatolia, Turkey

5

6 Authors:

7 Christina Collins ${ }^{1 *}$, Eleni Asouti $^{2}$, Matt Grove ${ }^{2}$, Ceren Kabukcu ${ }^{2}$, Lee Bradley ${ }^{3}$, Richard

8 Chiverrell $^{4}$

$9 \quad{ }^{1}$ College of Life and Environmental Sciences, University of Exeter, Penryn Campus, Penryn,

10 Cornwall, TR10 9FE, UK

11 2Department of Archaeology, Classics and Egyptology, University of Liverpool, 12-14 Abercromby

12 Square, Liverpool L69 7WZ, UK

$13{ }^{3}$ School of Science and the Environment, Manchester Metropolitan University, John Dalton Building,

14 Chester Street, Manchester, M1 5GD

$15{ }^{4}$ Department of Geography and Planning, University of Liverpool, Roxby Building, 74 Bedford Street

16 South, Liverpool, L69 7ZT, UK

$17 *$ Corresponding author

Email: c.collins4@exeter.ac.uk (Christina Collins)

christina.mary.collins@gmail.com

Email: e.asouti@liverpool.ac.uk (Eleni Asouti)

Email: matt.grove@liverpool.ac.uk (Matt Grove)

Email: c.kabukcu@liverpool.ac.uk (Ceren Kabukcu)

Email: 1.bradley@mmu.ac.uk (Lee Bradley)

Email: r.c.chiverrell@liverpool.ac.uk (Richard Chiverrell)

Address of corresponding author:

Dr Christina Collins

College of Life and Environmental Sciences

29 University of Exeter

30 Penryn Campus

31 TR10 9FE 


\title{
Understanding Resource Choice at the transition from foraging to farming: An application of palaeodistribution modelling to the Neolithic of the Konya plain, south- central Anatolia, Turkey
}

\section{Christina Collins $^{1 *}$, Eleni Asouti ${ }^{2}$, Matt Grove ${ }^{2}$, Ceren Kabukcu ${ }^{2}$, Lee Bradley ${ }^{3}$, Richard Chiverrell ${ }^{4}$}

${ }^{1}$ College of Life and Environmental Sciences, University of Exeter, Penryn Campus, Penryn, Cornwall, TR10 9FE, UK

${ }^{2}$ Department of Archaeology, Classics and Egyptology, University of Liverpool, 12-14 Abercromby Square, Liverpool L69 7WZ, UK

${ }^{3}$ School of Science and the Environment, Manchester Metropolitan University, John Dalton Building, Chester Street, Manchester, M1 5GD

${ }^{4}$ Department of Geography and Planning, University of Liverpool, Roxby Building, 74 Bedford Street South, Liverpool, L69 7ZT, UK

\begin{abstract}
The role of the environment in shaping agricultural origins is still not fully understood, despite a century of debate on this topic. Comparison of the expected prevalence of a resource in the landscape with actual archaeological presence of the same resource can provide a metric for assessing resource choice in prehistory. However, the palaeoenvironmental data that would allow resource choice to be evaluated in this way are rarely available. Species Distribution Modelling (SDM) techniques allow independent palaeoenvironmental datasets to be computed, which when compared to actual species' presence at sites as attested by archaeological datasets, can provide data on resource choice. Following recent calls for SDM to be applied more widely in archaeological contexts, we outline a simple method for predicting the presence of plant species in prehistory using modern analogues and palaeoclimatic datasets. These modelled distributions provide an independent dataset for comparison with archaeological data, thus providing a window into human resource choice in prehistory. We outline the method with specific reference to the transition from foraging to farming in the Neolithic of Central Anatolia, but the method could be applied to any period or region. We have used exclusively open source data and provided all code in our online supplementary materials, so that our method can be utilized by researchers interested in human resource choice in any region of the world and any period.
\end{abstract}

\footnotetext{
* Corresponding author
}

Email addresses: c.collins4@exeter.ac.uk; christina.mary.collins@ gmail.com (Christina Collins), e.asouti@liverpool.ac.uk (Eleni Asouti), matt.grove@liverpool.ac.uk (Matt Grove), c.kabukcu@liverpool.ac.uk (Ceren Kabukcu), 1.bradley@mmu.ac.uk (Lee Bradley), r.c.chiverrell@liverpool.ac.uk (Richard Chiverrell) 
Keywords: Neolithic; Turkey; Agriculture; GIS; Palaeodistribution modelling; Palaeoenvironment

\section{Introduction}

Palaeoenvironmental reconstruction, as practiced within archaeological contexts, typically assumes that palaeoecological assemblages are representative of the landscape and climate in which they were deposited. This is the case whether it is the climate or the local vegetation that is being reconstructed. A common approach to quantifying past climate variables from pollen cores is to identify modern analogue counterparts for identified fossil taxa, taking the overlapping range of these species' modern tolerances as the likely past climate range at the site of interest (Guiot, 1990). This method has been widely applied to a variety of Pleistocene and Holocene pollen assemblages, both for regional climate reconstruction (e.g., Chedaddi et al., 1998) and at the continental scale (e.g., Davis et al., 2003). Similarly, where the object of palaeoenvironmental reconstruction is the vegetation history of a particular landscape, the pollen or macro-charcoal assemblages are assumed to be representative of the palaeolandscape subject to an evaluation of their taphonomic histories (e.g., Bottema and Woldring, 1984; Chabal et al., 1999).

Such approaches to palaeoenvironmental reconstruction have several shortcomings, with most palaeoenvironmental datasets being subject to biases. In the case of pollen assemblages, both differential dispersal and preservation can skew the datasets (Campbell, 1999). Anthracological and faunal assemblages suffer from similar biases in addition to being further skewed by human resource choice, as humans practice selective foraging in the surrounding habitat; available floral and faunal species will not be uniformly selected, and thus will not form a true representation of the available resources (Asouti and Austin, 2005; Picornell et al., 2011).

While these biases can be problematic for palaeoenvironmental reconstructions, they are potentially useful for archaeological interpretation; any discrepancy between these assemblages and the actual expected distribution of resources in the landscape will provide a window into human resource choice in prehistory. To compare the distribution of flora and fauna in a prehistoric landscape with their presence in archaeological assemblages, an independent record of their presence is required; a record that does not originate directly from the archaeological data. Such an independent record can be obtained using Species 
Distribution Modelling (SDM) (for an overview see Elith and Leathwick, 2009) an approach that is theoretically opposed to traditional palaeoenvironmental reconstruction methods. While palaeoenvironmental modelling through the 'Mutual Climatic Range' method (Pross et al., 2000) uses the climatic range of modern analogue species to infer the climate of a given site in the past, SDM typically utilizes independent palaeoclimatic models or data to hind cast the presence of a species in prehistory, based on the same observed climatic range of modern analogue species (Franklin, 1995; Svenning et al., 2011). Furthermore, there is no a priori reason to believe that there are true modern analogues for prehistoric environments. SDM avoids this problem by treating each species separately and reconstructing prehistoric guilds from the bottom up (Svenning et al., 2011).

Following recent calls for SDM to be more widely applied in archaeology and palaeoanthropology (Franklin et al., 2015), we present a comprehensive example of the method as applied to the Neolithic of the Konya plain, in central Anatolia, Turkey, a study region and period of great archaeological and palaeoecological interest for understanding the origin of agriculture in Southwest Asia and its subsequent spread into Europe (cf. Roberts et al., 2001; Asouti, 2006). In addition to providing a pertinent example of SDM as applied to an archaeological context, we also illustrate how SDM can provide the independent palaeoenvironmental reconstruction that is required if we are to obtain meaningful insights into the nature of human resource choice in prehistory.

\section{The regional geographical and archaeological setting}

The Konya basin is an endoreic, high-altitude ( 1000 m a.s.l.) intramontane steppe plateau. The climate today is continental semi-arid, and the landscape has been heavily irrigated for farmland. In the recent past the plain was noted for its extensive marshlands, lakes, and seasonal water bodies (de Meester, 1970) which have largely disappeared within the past thirty years (Asouti and Kabukcu, 2014). A large palaeolake covered much of the plateau in the late Pleistocene, which dried up around 17,000 BP leaving large areas of marl across its former range (Roberts et al., 1999).

As an early locus of Neolithic communities outside the Fertile Crescent, the Konya Plain represents a key archaeological landscape for understanding the spread of early food production and Neolithic lifeways into central and western Anatolia and southeast Europe. The transition from foraging, through to cultivator-forager and farming economies $(\sim 15,000$ - 
1329000 cal BP) can be traced through the local prehistoric archaeological sequence (Baird,

133 2012; Baird et al., 2012, 2013; see also Fig. 1). The rock-shelter and open-air sites of

134 Pınarbaşı, at the foothills of the volcanic massif of Karadağ, on the shores of the Hotamış

135 depression were the focus of prehistoric occupation from the end of the Pleistocene through

136 to the $11^{\text {th }}$ millennium cal BP, including a late phase of pastoral campsite activity dating from

137 the $9^{\text {th }}$ millennium cal BP (Baird et al., 2011, 2013). With regard to the Neolithic period $\left(11^{\text {th }}\right.$ -

$1389^{\text {th }}$ millennia cal BP) the available archaeobotanical datasets indicate that neither

139 domesticated crops nor their wild progenitors were present at Pınarbaşı (Fairbairn et al.,

140 2014). Boncuklu höyük (8300-7500 cal BC (Baird, per comm, 2018) is a small Neolithic tell

141 site to the northwest of Pınarbaş1, with evidence for year-round settlement and a local

142 economy heavily reliant on hunting with some evidence for the local adoption of some

143 domesticated crops (Baird, 2012). At the much larger Neolithic site of Çatalhöyük East, 8.5

$144 \mathrm{~km}$ to the southwest of Boncuklu, mixed agropastoral production, based on crop cultivation

145 and caprine herding, formed the mainstay of the local economy throughout its long habitation

146 history ( 9100-8000 cal BP) (cf. Hodder, 2007; Bogaard et al., 2013). 


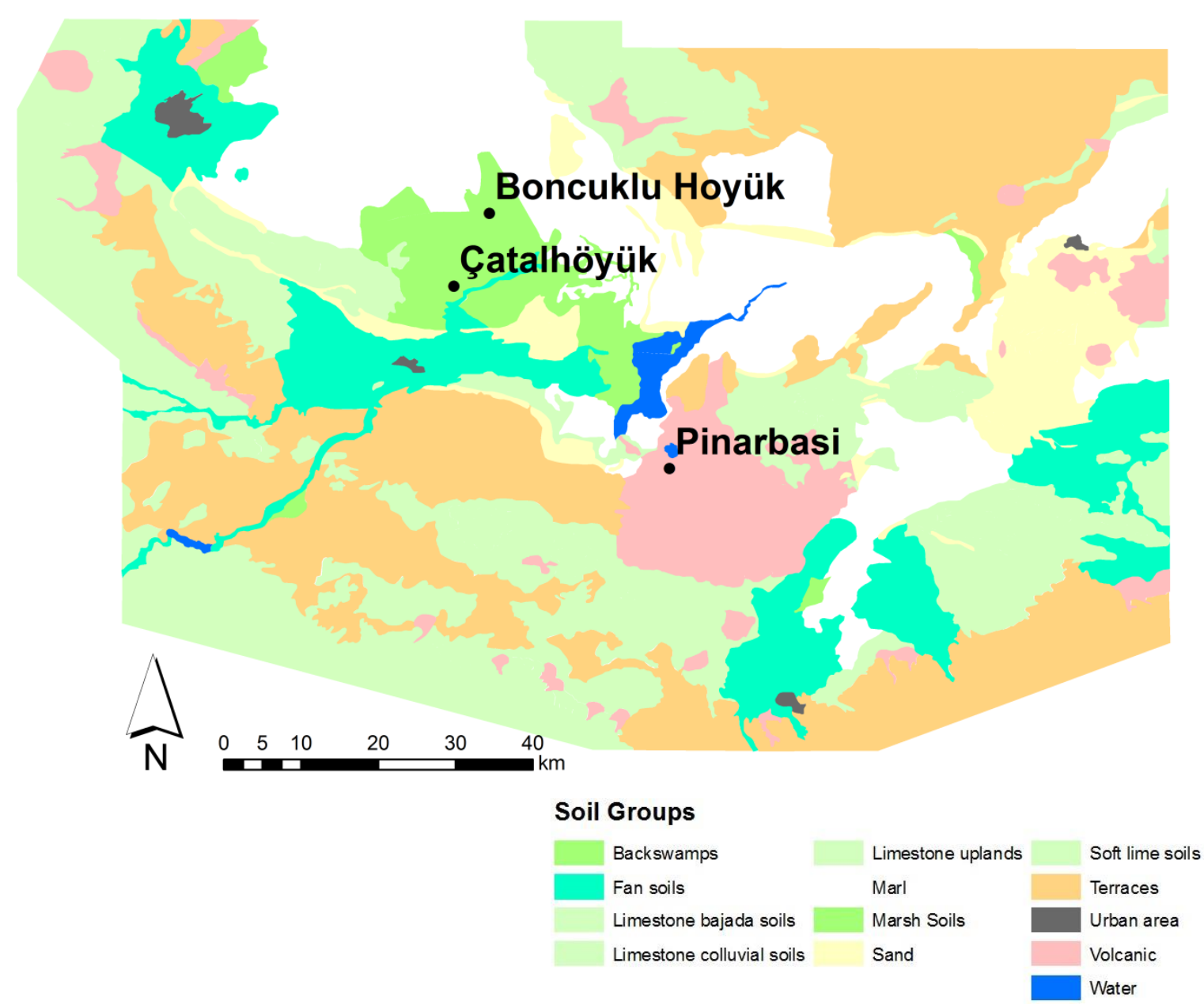

Figure 1: Map of the major modern landscape units of the Konya basin (modified after de Meester, 1970). The locations of key archaeological sites mentioned in the text are shown.

\section{Material and methods}

\subsection{Species Distribution Modelling (SDM) method}

SDM represents a powerful tool for approaching palaeoenvironmental reconstruction in the context of prehistoric archaeology, due to its independently produced projections of past resource distributions which, when compared to zooarchaeological, anthracological and archaeobotanical datasets, permit archaeologists to obtain unique insights into past human resource choice (Franklin et al., 2015). Species included in SDM were selected based on their relevance to the geographic region (see also Table 1). We used locality data from the Global Biodiversity Information Facility (GBIF) (www.gbif.org), querying the database for each species of interest by species name. We obtained modern climate data from worldclim.org (Hijmans et al, 2005), elevation data for Turkey at 90m resolution from the 
SRTM (Shuttle Radar topography mission) (Jarvis et al, 2006; http://srtm.csi.cgiar.org), and global elevation data at 5 minute resolution from Terrain BASE ( ftp://ftp.ngdc.noaa.gov/Solid_Earth/cdroms/TerrainBase_94/data/global/tbase/tbase.txt ). For each species of interest, modern presence data (MPD) were downloaded from the GBIF. Species MPD were then clipped to a geographical range encompassing the Mediterranean, Southern, Central and Western Europe and the Near East. This geographical range (Fig. 2) was selected to exclude any samples held in artificial research environments, outside of their potential natural environmental ranges. A minimum of 50 locality samples were obtained for each species of interest; where the GBIF sample size was insufficient, we supplemented plant species data from additional sources such as the Flora of Turkey (Davis, 1965).

Modern mean monthly temperature and mean monthly precipitation layers were obtained from worldclim.org. Mean monthly temperature layers were used to compute the variable of Effective Temperature (ET - equation 1) which incorporates the temperatures of both the mean warmest month and the mean coldest month and relates to the length of the plant growing season (Bailey, 1960).

$$
\mathrm{ET}=\left[(18 \mathrm{xMWM})-\frac{(10 \mathrm{xMCM})}{(\mathrm{MWM}-\mathrm{MCM})}+8\right]
$$

Mean annual precipitation was also computed from the monthly data. In addition to these climatic layers, an additional global elevation layer was incorporated into the analysis, used as a proxy for 'frost days', which we found in preliminary runs to be a useful predictor of the occurrence for plant species in the semi-arid, continental climate regime characterising the Konya plain. 'Frost days' have featured in combination with other geographic variables in several predictive modelling studies, and have been shown to successfully predict the distribution of several plant and animal species (e.g., Castro et al., 2008). Frost days have been shown to be a limiting factor in the distribution of beech trees in Europe (Bolte et al., 2007).

Presence point data for each species of interest were overlaid onto the three abiotic layers of ET, annual precipitation, and elevation, which were then sampled at these locations. We explored the empirical univariate distribution of these variables for several plant species and found that in most cases these variables were normally distributed, as we would expect following Shelford's law of tolerance (Shelford, 1931). The resulting multivariate distribution 
was interpreted as the fundamental niche of each species. The fundamental niche of a species corresponds to the multidimensional realm that it could potentially inhabit (Hutchinson, 1957). However, the fundamental niche is rarely realized, due to the impacts of historical or anthropogenic factors. Instead, most species' distributions will represent their realized niche; i.e., a smaller subset of the range that could be occupied by a species in the absence of competition or human intervention. Natural barriers are also likely to limit the actual dispersal of a species, hence also contributing to the ultimate shape of the realized niche.

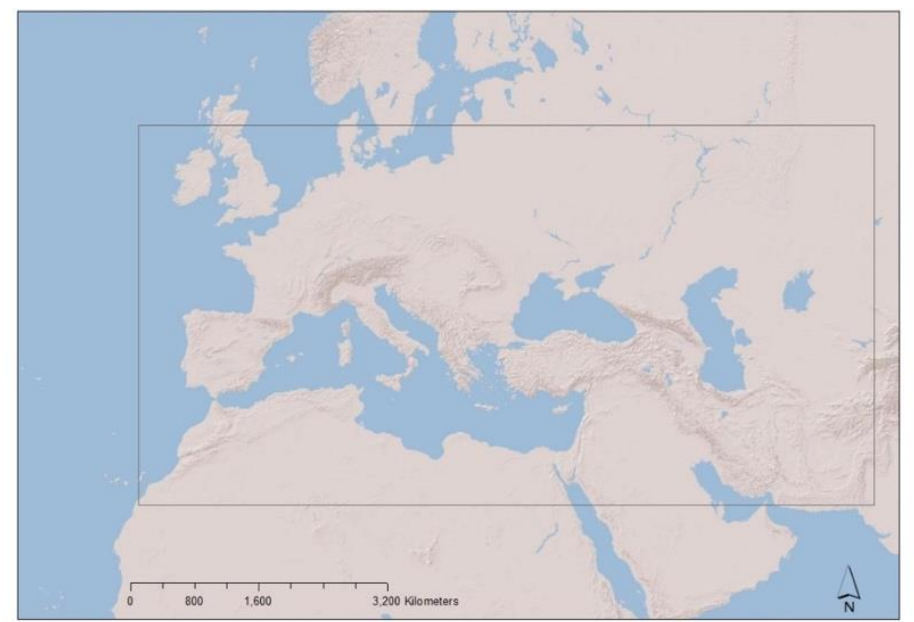

Figure 2: Outline of the study region: locality samples were obtained from within the delimited range.

Inevitably, the modern presence data used in this study are drawn from the realized niche of each species. Since the modelled distribution based on this sample cannot take account of any historical or competitive factors that will limit species distributions, it represents an approximation of the fundamental niche, termed the Projected Fundamental Niche (PFN). It must be noted that it is possible that species' niches might have changed from the early Holocene to the present day, although given the relatively limited time depth it seems unlikely that any such changes might have impacted significantly the modelling of PFNs.

Unlike traditional palaeoenvironmental modelling, which draws on mutual climatic ranges, SDM requires palaeoclimatic data as an input. Palaeoclimatic records from Anatolia have indicated a rapid increase in humidity with the onset of the Holocene, as evidenced in stable isotope and pollen from Lake Van in eastern Anatolia (Wick et al., 2003). Analysis of speleothems from Southwest Asia also point to an increase in moisture at the onset of the Holocene, with higher values suggested by comparison to both the Younger Dryas and the present-day (Göktürk et al., 2011; Orland et al., 2012). However, such speleothem and isotope sequences only inform us about relative changes in precipitation, temperature and 
seasonality, and cannot be readily translated into absolute temperature and precipitation values (see also Jones et al., 2007). Equally while climate models also provide high temporal resolution time-slices for the Holocene (e.g., Braconnot et al., 2007) these are frequently characterised by low spatial resolution. Thus, for the present study species distributions were modelled for a low-resolution sequence comprising just two phases: an early Holocene and a late Holocene phase. Temperature and precipitation changes from the present to the early and the late Holocene were based on estimates provided for the neighbouring region of Cappadocia in central Anatolia by Jones et al. (2007) based on hydrological and oxygen stable isotope mass balance models. We used the difference between the modern and Early Holocene average annual temperature and annual precipitation for Cappadocia to obtain a transformation that could be used to convert the modern ET and precipitation layers into early Holocene layers, through addition or subtraction at each pixel. This approach assumes that temperature and precipitation in Central Anatolia has altered in a uniform manner across space, which while almost certainly a simplification of the actual pattern of climate change in the region, is the closest we can come to obtaining absolute values for temperature and precipitation for Konya as most palaeoclimatic archives available for the Konya region provide only relative climatic data.

Individual species distribution models were produced for all plant and animal species in the manner outlined above and summary statistics (mean and standard deviation) were collected. Table 1 shows the number of specimens for each species within the study region. All locality data were derived from the GBIF, with some exceptions. Additional Juniperus excelsa data were derived from The Flora of Turkey (Davis, 1965), and The Atlas of the World's Conifers (Farjon and Filer, 2013). Quercus cerris, Q. pubescens and Populus tremula data are derived from the Flora of Turkey (Davis, 1965). Crataegus orientalis is a composite of data from the GBIF and the Flora of Turkey. Amygdalus orientalis data were derived from the Flora of Turkey, and Browicz and Zohary (1996) while Celtis tournefortii data were derived from the GBIF (C. glabrata and C. tournefortii), the Turkish Plants Data Service (www.tubives.com) and Flora Europaea (Tutin et al, 2010). Carex divisa locality data from the GBIF. Lens culinaris ssp. orientalis data were derived from the GBIF and the Flora of Turkey. Lastly, due to the low number of available sample points, the geographic range of Tamarix parviflora was extended slightly outside the limits of the study region to reach the minimum requirement of 50 samples. Where samples exceeded 3000 data points, a random sub-sample of 3000 points was taken. 
253 Table 1: Plant species used in the study and number of sample points

\begin{tabular}{|l|l|}
\hline Plant species & N of sample points \\
\hline Quercus cerris & 113 \\
\hline Quercus pubescens & 99 \\
\hline Populus tremula & 172 \\
\hline Juniperus excelsa & 72 \\
\hline Celtis tournefortii & 59 \\
\hline Amygdalus orientalis & 112 \\
\hline Fraxinus angustifolia & 1245 \\
\hline Tamarix parviflora & 104 \\
\hline Ficus carica & 2896 \\
\hline Ulmus minor & 3000 \\
\hline Salix alba & 3000 \\
\hline Pistacia atlantica & 530 \\
\hline Pistacia terebinthus & 1375 \\
\hline Crataegus orientalis & 76 \\
\hline Acer monspessulanum & 583 \\
\hline Hordeum vulgare ssp. spontaneum & 540 \\
\hline Bolboschoenus glaucus & 183 \\
\hline Aegilops neglecta & 742 \\
\hline Aeluropus littoralis & 242 \\
\hline Bromus arvensis & 2689 \\
\hline Carex divisa & 1771 \\
\hline Festuca ovina & 2999 \\
\hline Hordeum bulbosum & 1208 \\
\hline Stipa holosericea & 71 \\
\hline Triticum turgidum ssp. dicoccoides & 155 \\
\hline Triticum monococcum ssp. boeoticum & 224 \\
\hline Chenopodium album & 3000 \\
\hline Lens culinaris ssp. orientalis & 51 \\
\hline Cicer reticulatum & 77 \\
\hline Pisum sativum ssp. elatius & 217 \\
\hline Vicia ervilia & 942 \\
\hline Artemisia herba-alba & 2751 \\
\hline & \\
\hline
\end{tabular}

In addition to modelling the vegetation based on their observed ET, precipitation and elevation, we included soil types as a factor in the model. The extensive Konya plain soil

257 survey conducted by de Meester (1970) provided the basis for this and we have used this soil 258 map as a layer in our model. Soil-vegetation compatibility was determined based on

259 ecological factors including species autecology alongside historical and modern fieldwork

260 data (see overview in Asouti and Kabukcu, 2014) and incompatible soils were then 'switched

261 off' in the model, so that a patch featuring an incompatible soil is always given a PFN of 0.

262 Compatible soils for each modelled plant species are shown in Table 1. The PFN varies 
spatially, as it is dependent on the geographic input layers (eg ET, precipitation). We refer to the spatially varying field of PFN values as the 'PFN surface'.

Table 2: Plant species and compatible soil types

\begin{tabular}{|l|l|}
\hline Plant species & Compatible soil type \\
\hline Quercus cerris & Limestone, terraces, volcanic \\
\hline Quercus pubescens & Limestone, terraces, volcanic \\
\hline Populus tremula & "Backswamp" \\
\hline Juniperus excelsa & Limestone, terraces \\
\hline Celtis tournefortii & Limestone, fan soils, terraces, volcanic \\
\hline Amygdalus orientalis & Limestone, fan soils, terraces, volcanic \\
\hline Fraxinus angustifolia & Fan soils, terraces \\
\hline Tamarix parviflora & "Backswamp", fan soils \\
\hline Ficus carica & Fan soils, terraces \\
\hline Ulmus minor & Fan soils, terraces \\
\hline Salix alba & "Backswamp" \\
\hline Pistacia atlantica & Limestone, terraces, volcanic \\
\hline Pistacia terebinthus & Limestone, terraces, volcanic \\
\hline Crataegus orientalis & Limestone, fan soils, terraces, volcanic \\
\hline Acer monspessulanum & Limestone, fan soils, terraces \\
\hline Hordeum vulgare ssp. spontaneum & Limestone, fan soils, terraces, volcanic \\
\hline Bolboschoenus glaucus & "Backswamp" \\
\hline Aegilops neglecta & Terraces, marl, volcanic \\
\hline Aeluropus littoralis & "Backswamp" \\
\hline Bromus arvensis & Terraces, marl, volcanic \\
\hline Carex divisa & "Backswamp", fan soils \\
\hline Festuca ovina & Terraces, marl, sand, volcanic \\
\hline Hordeum bulbosum & Terraces, volcanic \\
\hline Stipa holosericea & Terraces, marl, volcanic \\
\hline Triticum turgidum ssp. dicoccoides & Limestone, terraces, volcanic \\
\hline Triticum monococcum ssp. boeoticum & Limestone, terraces, volcanic \\
\hline Chenopodium album & "Backswamp", marl, sand, alluvial \\
& sandy loams \\
\hline Lens culinaris ssp. orientalis & Limestone, terraces, volcanic \\
\hline Cicer reticulatum & Limestone, terraces, volcanic \\
\hline Pisum sativum ssp. elatius & Limestone, terraces, volcanic \\
\hline Vicia ervilia & Limestone, terraces, volcanic \\
\hline Artemisia herba-alba & Sand, marl \\
\hline & \\
\hline
\end{tabular}

\subsubsection{Testing the models}

As a test of the strength of the PFN, we removed a sample of $10 \%$ of datapoints for each species. We then recalculated the PFN based on the $90 \%$ of remaining datapoints. We then overlaid the excluded $10 \%$ of datapoints onto the PFN surface for that species, and sampled the PFN at these locations. This is similar to the approach to testing SDMs advocated by Copeland et al (2016). 
274 Testing the model in this way enables us to say how likely the model is to predict the presence of a species in a location where we know it to be present. However, due to the nature of the samples, we are unable to say how likely the model is to predict the presence of a species where it is not found. This is because we cannot say with any certain whether a particular species is definitively not found in any location, even where it is not present in the sample database at a location.

The results of the model tests for individual species are tabulated in the supplementary materials. Species are more likely to be present in a location where a high PFN is produced from the model. Therefore, in the test cases, species with the highest average PFN at locations where we know they are found, are species for which the models most accurately predict the presence of the species.

\subsection{Site Catchment Analysis method}

The Site Catchment Analysis method was introduced into archaeology through the work of Vita-Finzi and Higgs (1970) at Mount Carmel, Palestine. The method allows the relationship between the site and the wider environment to be understood, through mapping the site within the surrounding area and the resources found within this area. They reasoned that in general resources located further away from a site would be exploited less frequently than resources found immediately adjacent to the site, and they used an ethnographicallyderived distance of $10 \mathrm{~km}$ to represent a feasible distance from the site which huntergatherers would be prepared to regularly travel. The method has been critiqued and developed since the work of Vita-Finzi and Higgs (1970). Notably, their study has been criticised for relying on modern land use patterns to obtain data on past environmental conditions (Hodder and Orton, 1979). Likewise, the development of Least Cost Path approaches have built on the SCA method while incorporating more complex approaches to modelling human movement in the landscape, considering factors such as elevation, slope, terrain, and river systems (Surface-Evans and White, 2012).

Given that our method here is based on modelled PFN surfaces, we can overcome some of the issues of assuming modern land use and environmental patterns are analogous to the past. However, our results are influenced by modern data on the environment, in the form of the soil map produced by de Meester (1970). The approach that we have taken with producing the SCA model combines the effects of the distance from site with the perceived 
307

308

309

310

311

312

313

314

315

316

317

utility of each patch. Three layers are required to create the SCA: a layer containing the distance from the site, the PFN surface, and a further 'discounted PFN surface', calculated by [(PFN) - (distance from site)]. Discounted PFN surfaces are restricted to a $10 \mathrm{~km}$ radius of each site; this distance is ethnographically derived by Lee (1969), and widely used to approximate a two hour walk by hunter-gatherers in search of resources.

\section{Results}

Individual layers were produced, modelling the PFN surface for each plant species across the two phases (early and late Holocene). In general, there was good agreement between PFNs for the late Holocene and independent historical and fieldwork observations of species distributions in the Konya plain area. As an example, Figure 3 shows the PFN for

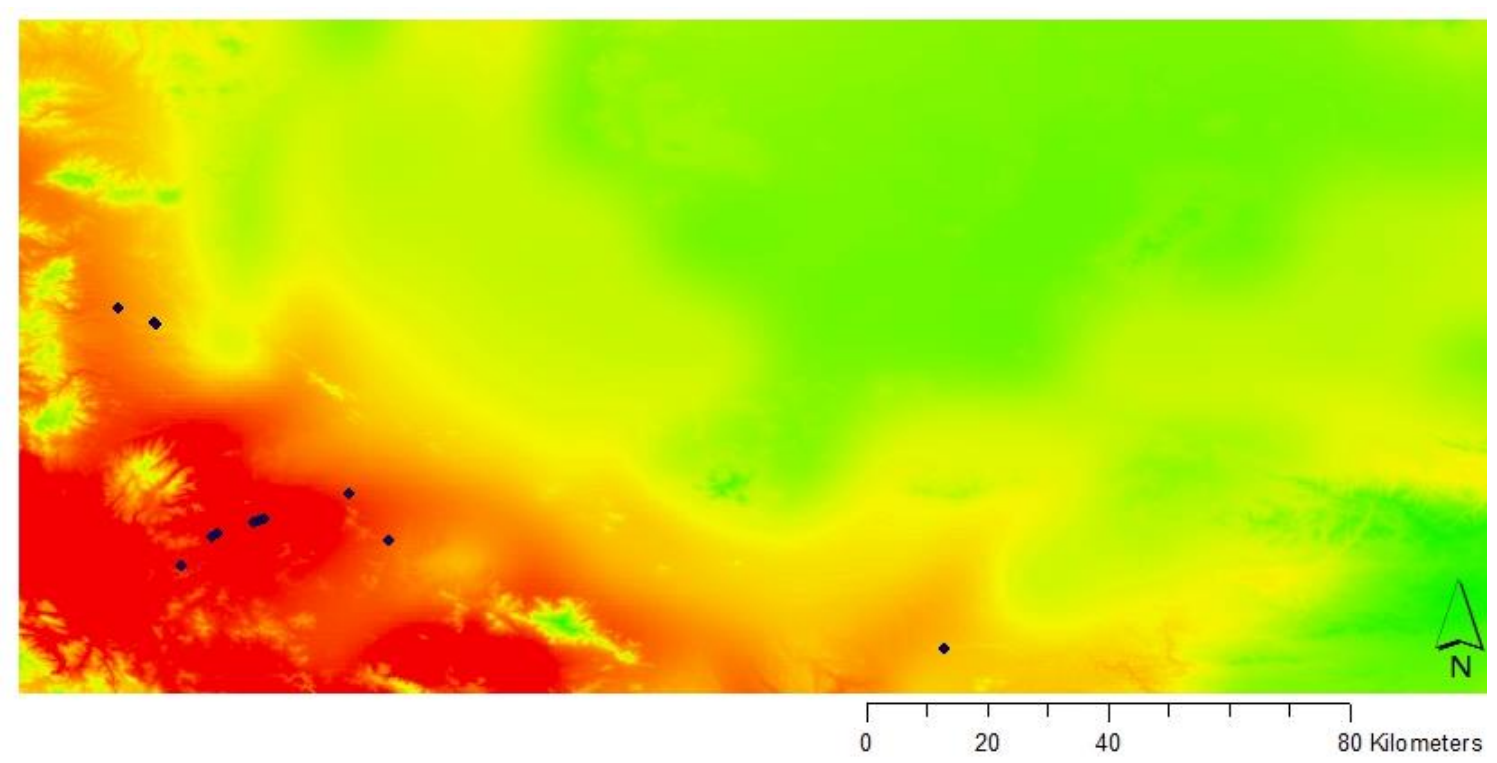

Figure 3: PFN values for Juniperus excelsa with observation points mapped on derived from Asouti and Kabukcu (2014)

Juniperus excelsa with observation points derived by Asouti and Kabukcu (2014) mapped on; all observation points occur in locations where there is a high (red) or moderate (amber) value for the PFN. The PFN is a number scaled between 0 and 1 which represents the likelihood of the species being found at a particular location.

After modelling the PFN for each species of interest, we collected summary statistics for individual layers; the maximum and mean pixel values for the plain. The distributions of species per these values are shown in the graphs below, with species organised into trees, 
327

328

329

330

331

332

333

334

335

336

337

338

339

340

341

342

grasses, and miscellaneous (shrubs, herbs). The individual modelled PFN surfaces for every species of interest can be found in the online supplementary materials, along with the python code used to generate these PFN surfaces in ArcMap. Any researcher can use this code, along with the open source palaeoclimatic data provided by worldclim.org, to model predicted species abundance in their period and location of interest.

Many results are shown grouped according to the 'predicted relative abundance' of the PFNs. For example, Figure 5, shows the distribution of the floral species in the vicinity of Boncuklu according to the average PFN value, standardized so that all of the species' 'predicted relative abundance' sum to 1 . These predicted relative abundances can therefore be treated as indicative of the frequency distributions of species within the area represented.

\subsection{Early Holocene Phase Results - Trees}

4.1.1. Maximum PFN, standardized, for all modelled tree species, across the Early Holocene Konya Plain

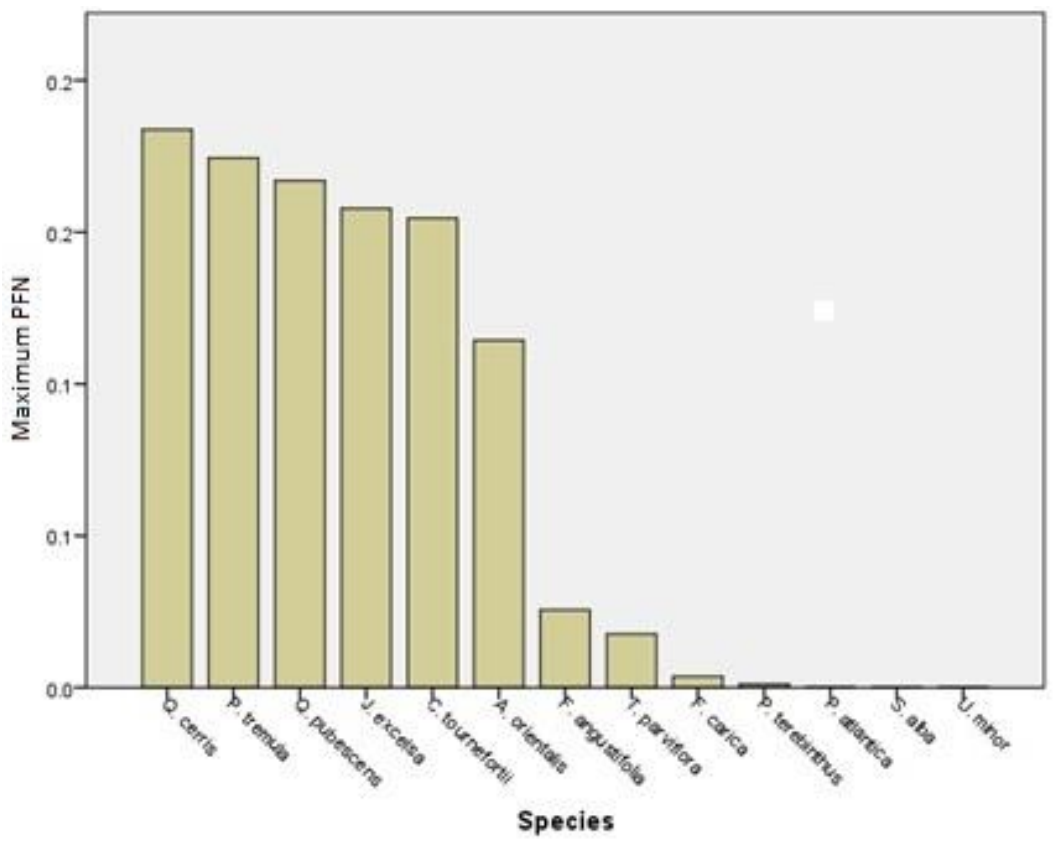

Figure 4: Distribution of modelled tree species Konya Plain. The Maximum PFN for each tree species, across the whole of the Early Holocene Konya Plain, is shown. 
4.1.2 Site Catchment Models (SCM): Distribution of trees within 10km radius of Early Holocene Boncuklu

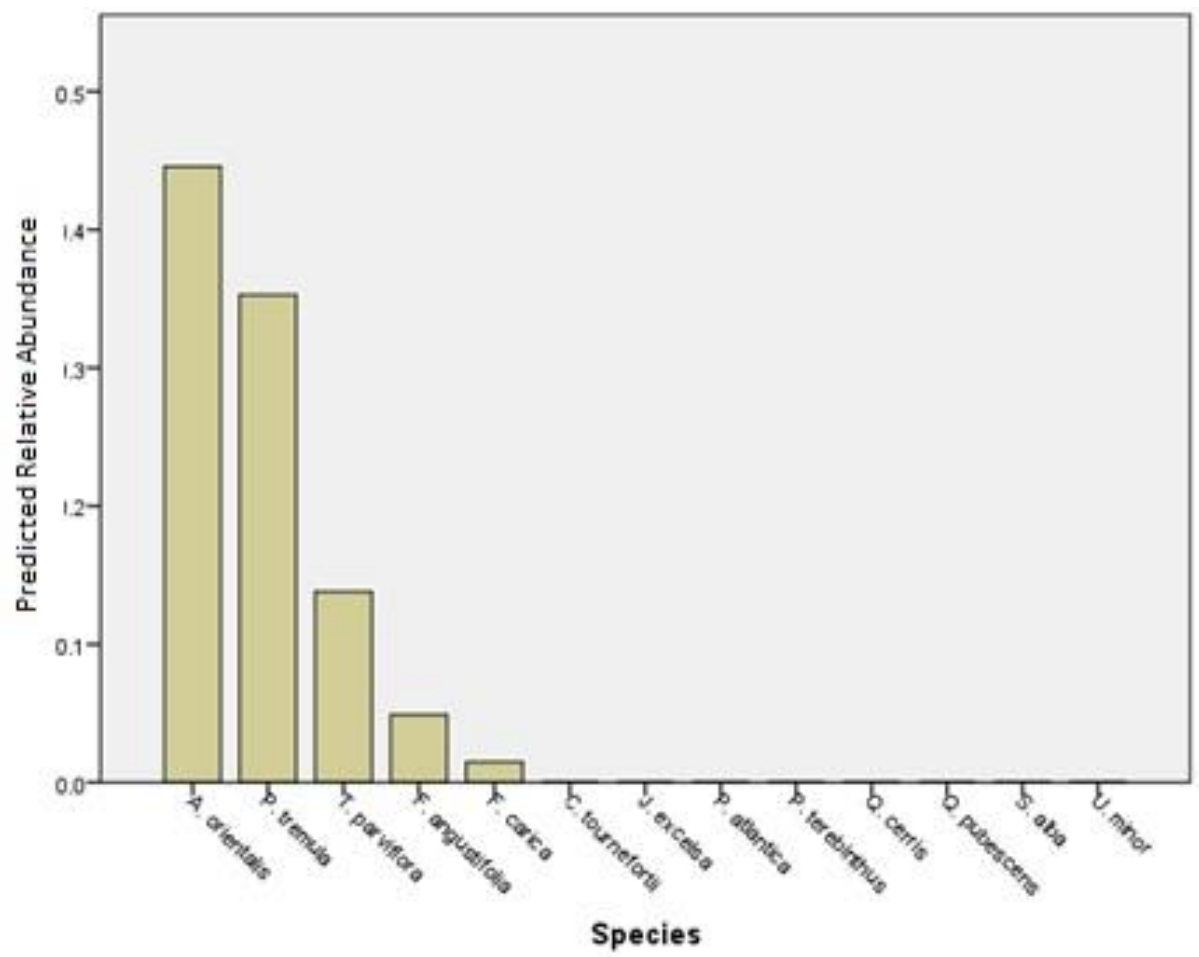

Figure 5: Distribution of modelled tree species, $10 \mathrm{~km}$ of Boncuklu.

Predicted Relative Abundance calculated from the PFN for each species

4.1.3. CM: Distribution of trees within $10 \mathrm{~km}$ radius of Early Holocene Pınarbaş1

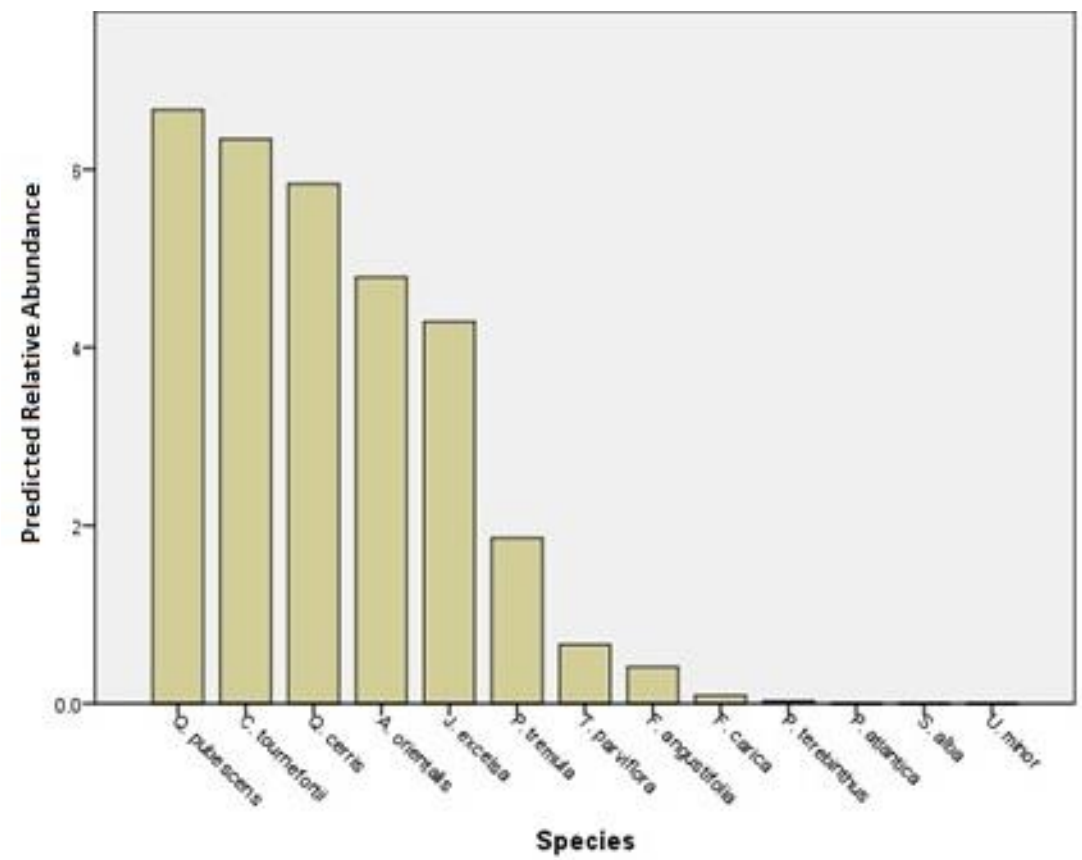

Figure 6: Distribution of modelled tree species, $10 \mathrm{~km}$ of PInarbaşı. Predicted Relative Abundance calculated from the PFN for each species 
4.1.4. SCM: Distribution of trees within $10 \mathrm{~km}$ radius of Early Holocene Çatalhöyük

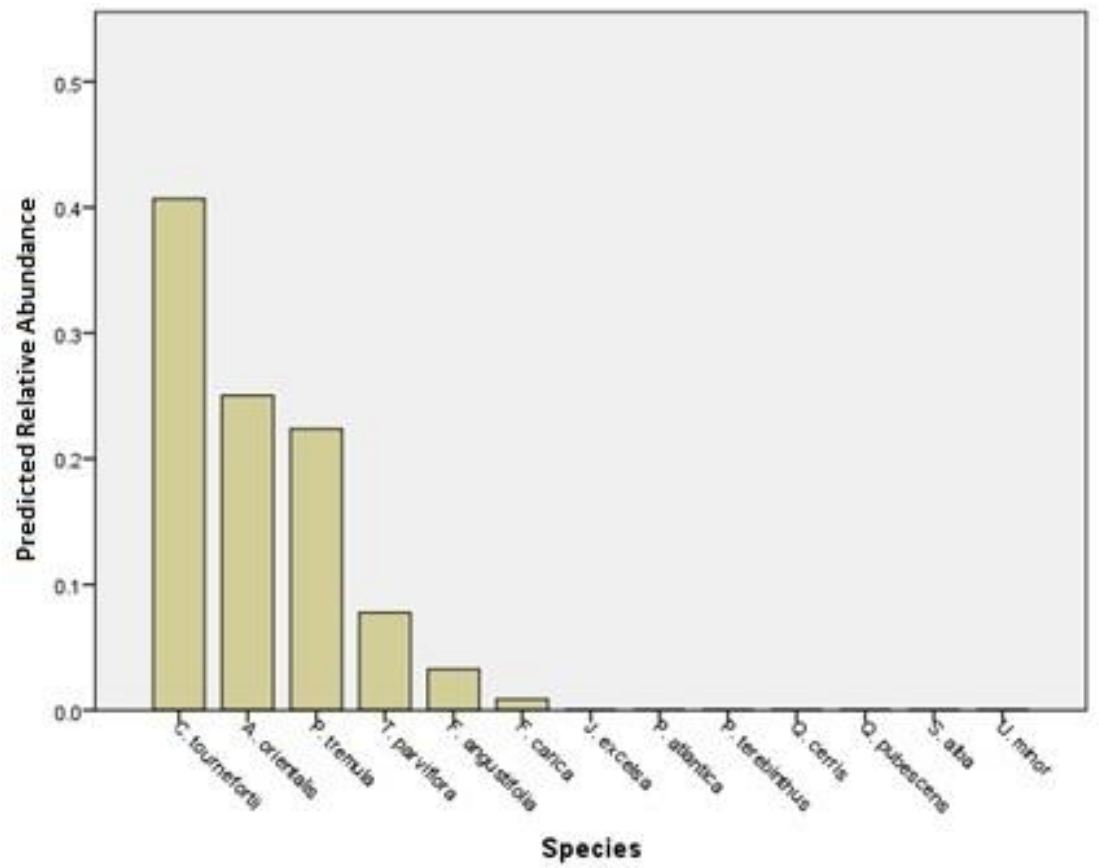

354

Figure 7: Distribution of modelled tree species, $10 \mathrm{~km}$ Çatalhöyük. Predicted Relative Abundance calculated from the PFN for each species 
356

357

358

359

4.2.1. Distribution of grass species across the Early Holocene Konya Plain

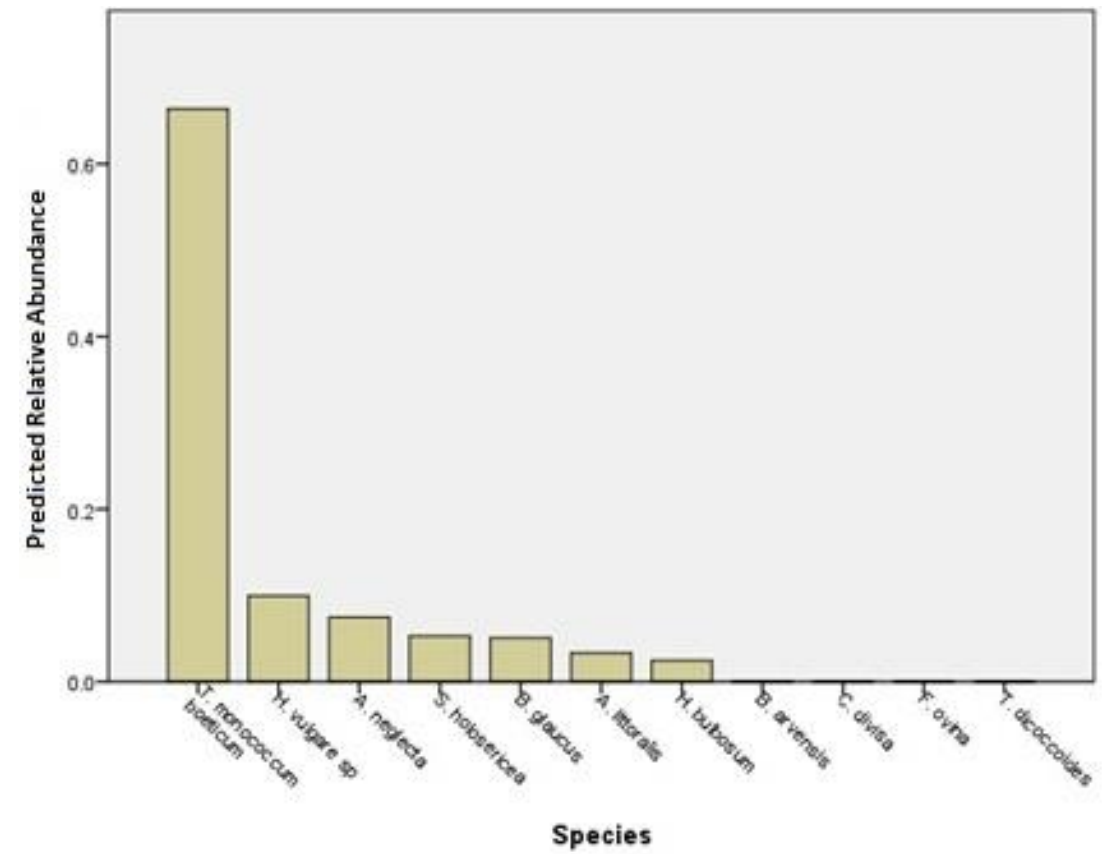

Figure 8: Distribution of modelled grass species, Konya Plain. Predicted Relative Abundance calculated from the PFN for each species 
383

384

385

386

Figure 9: Distribution of modelled grass species, $10 \mathrm{~km}$ Boncuklu. Predicted Relative Abundance calculated from the PFN for each species

4.2.2 SCM: Distribution of grasses within 10km radius of Early Holocene Boncuklu

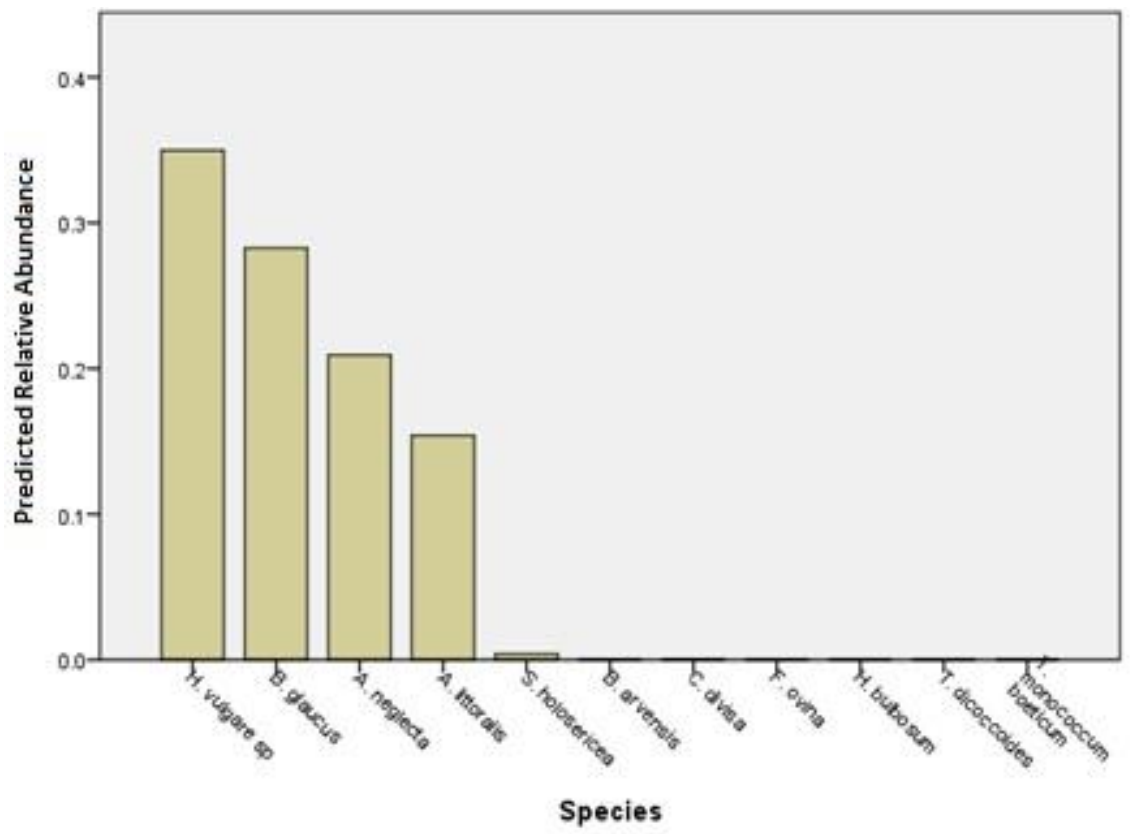

388

389

390

391

392

393

394

395

396

397

398

399

400 
401

402

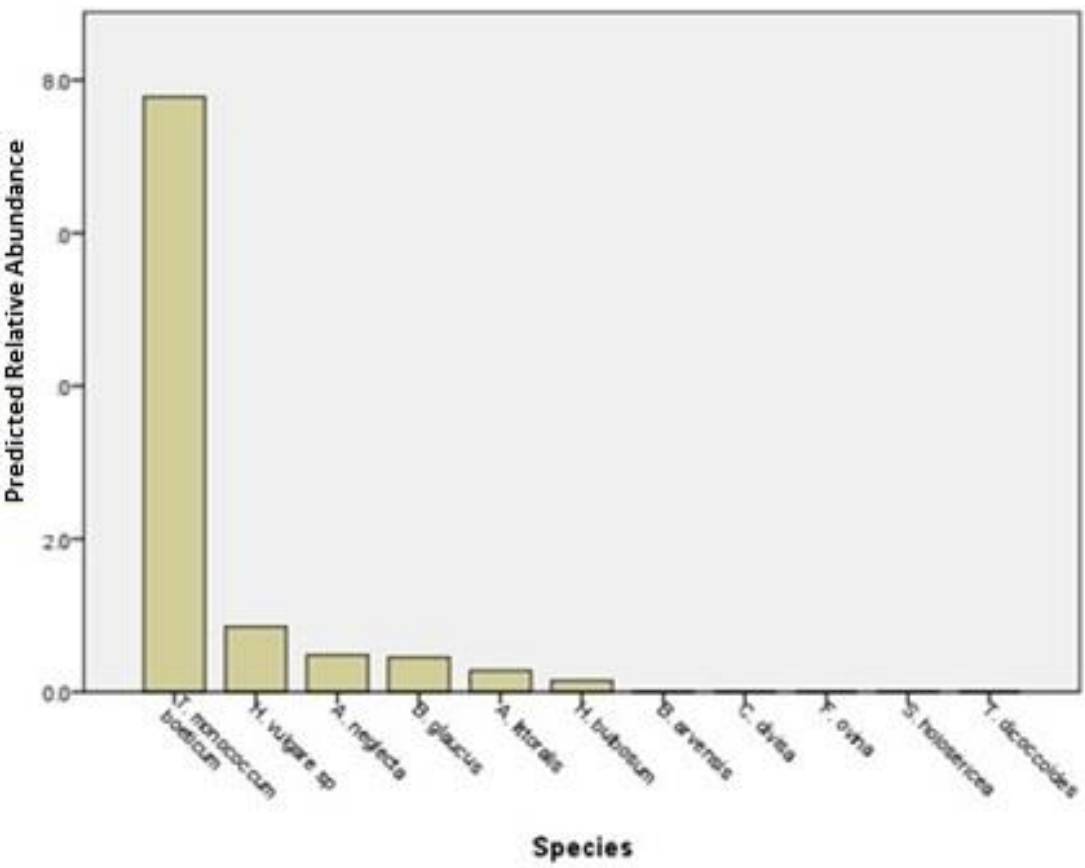

403

Figure 10: Distribution of modelled grass species, $10 \mathrm{~km}$ Pınarbaşı.

Predicted Relative Abundance calculated from the PFN for each species

4.2.2. SCM: Distribution of grasses within 10km radius of Early Holocene Pınarbaş1

Species
404

405

406

407

408

409

410

411

412

413

414

415

416 


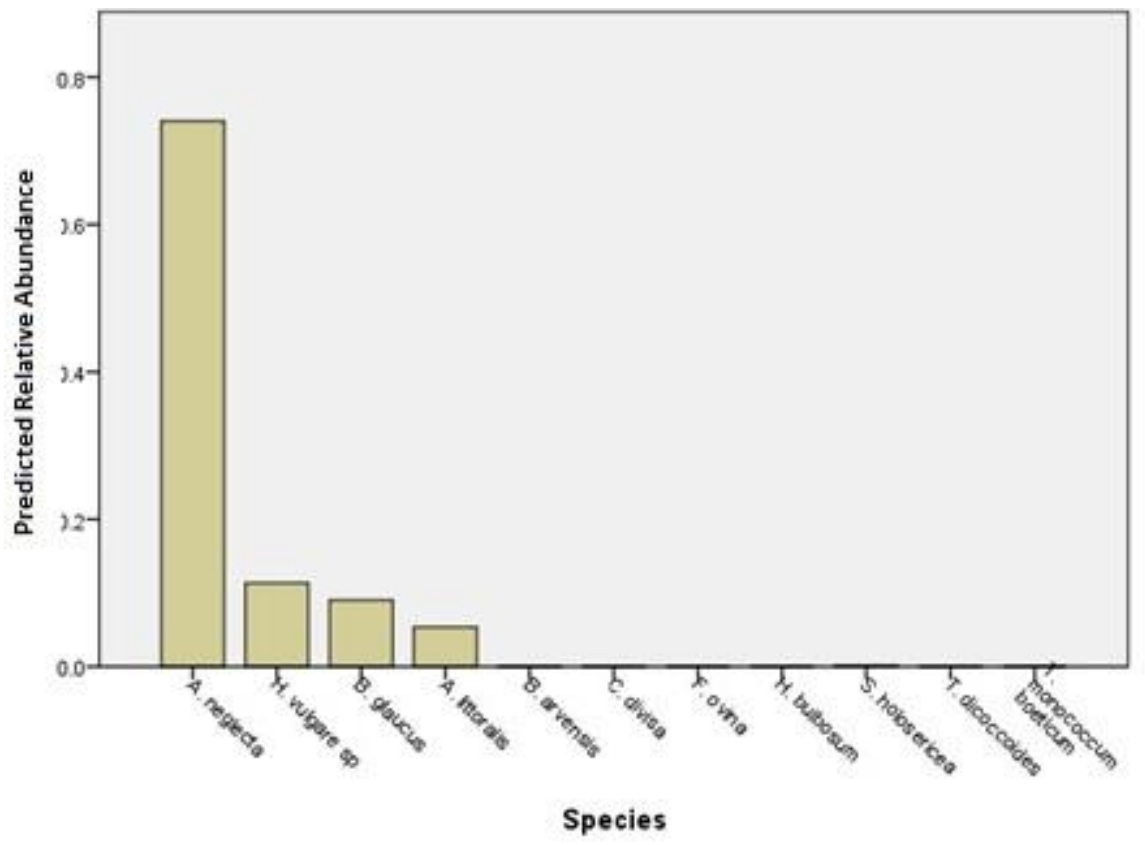

Figure 11: Distribution of modelled grass species, 10km Early Holocene Çatalhöyük. Predicted Relative Abundance calculated from the PFN for each species 
4.5.1. Summed PFN SCMs - Early Holocene trees $(10 \mathrm{~km}$ catchment area of Pınarbaşı, Boncuklu and Çatalhöyük, and the Konya plain)

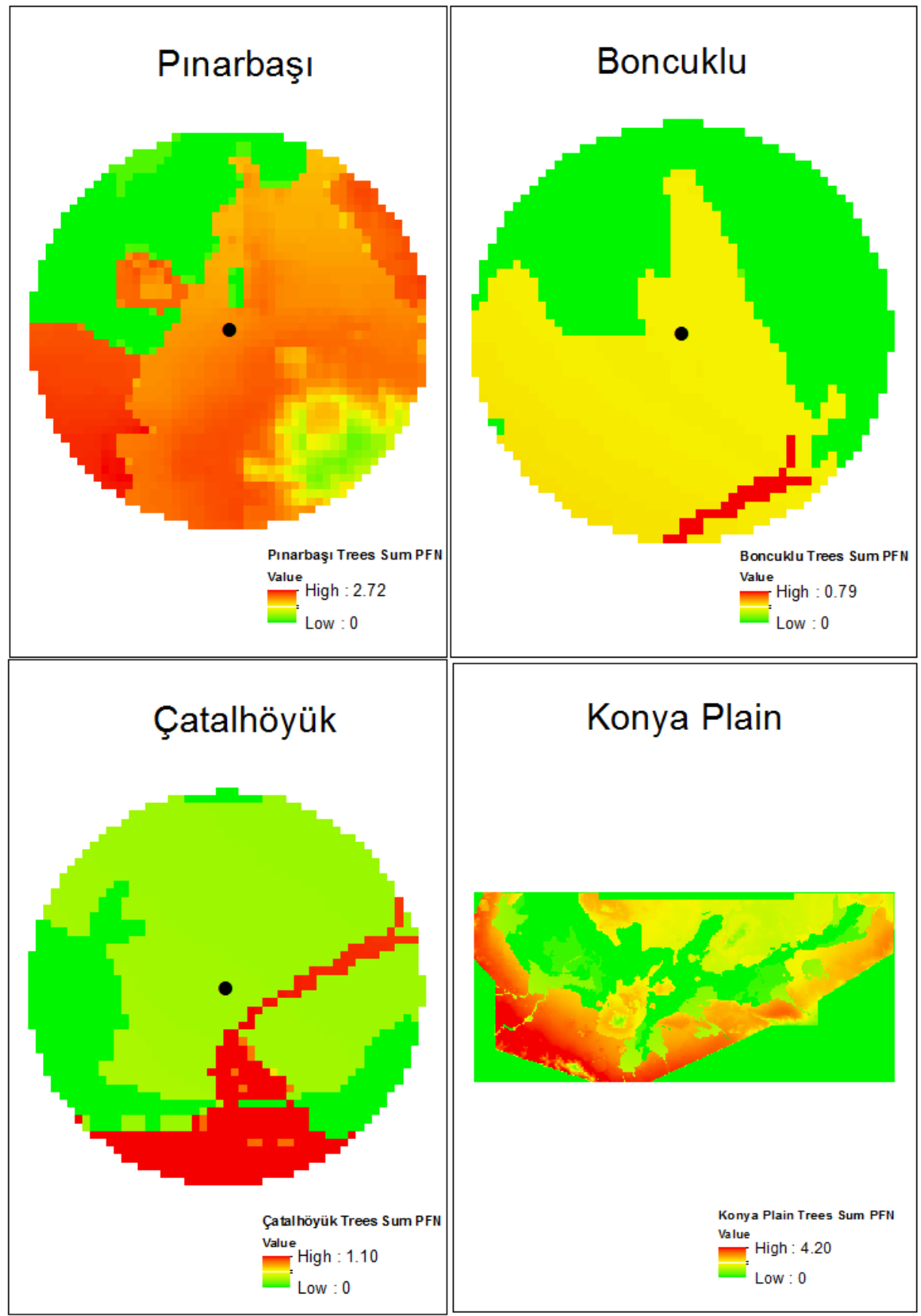

Figure 12: Summed PFN SCMs trees, $10 \mathrm{~km}$ radius of each site, and summed PFN for the entire Konya Plain 


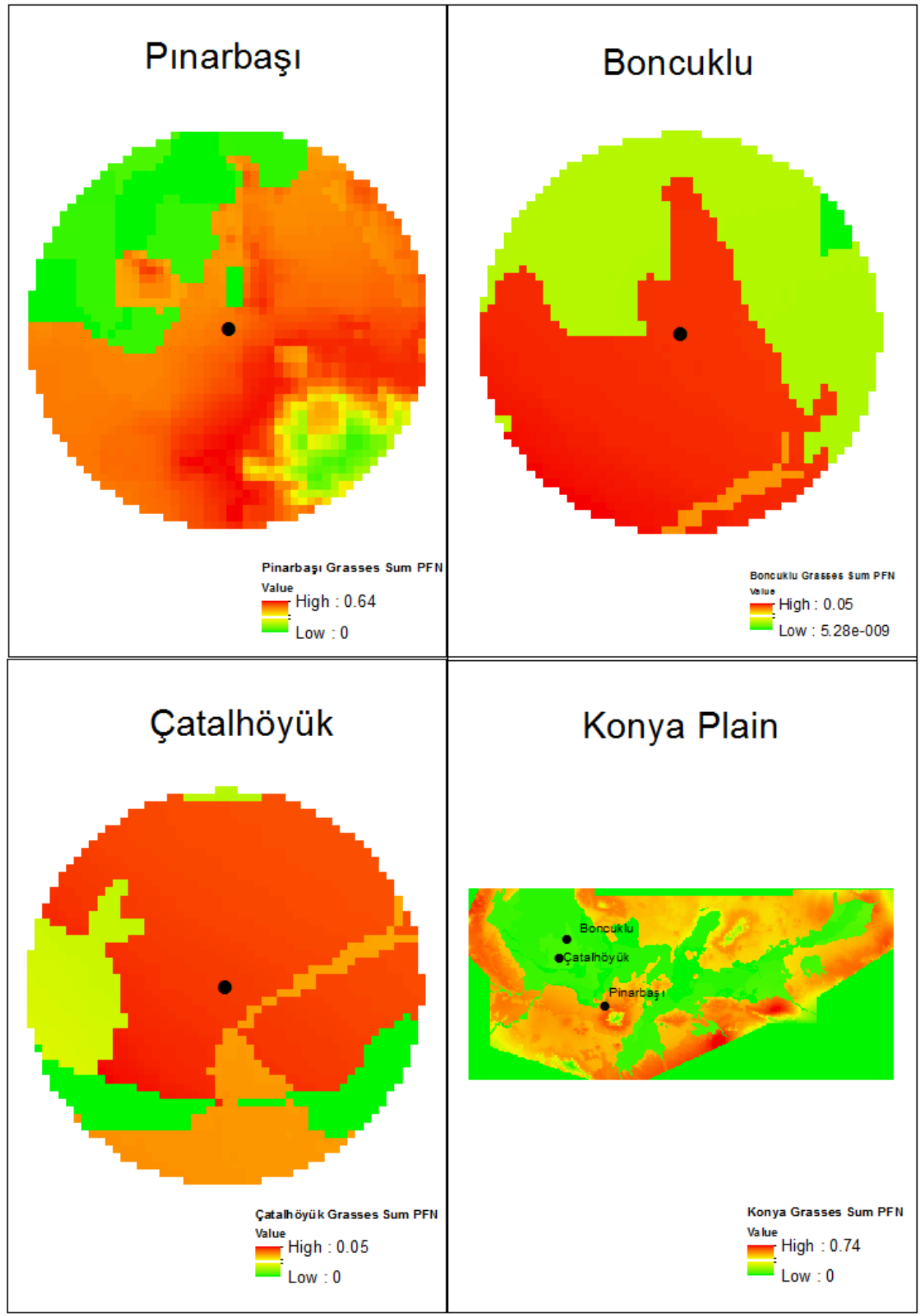

Figure 13: Summed PFN SCMs, grasses, $10 \mathrm{~km}$ radius of each site and for the entire Konya Plain 
4.5.3. Total Summed PFN SCMs (10 km catchment area of Pınarbaşı, Boncuklu and Çatalhöyük, and the Konya plain)

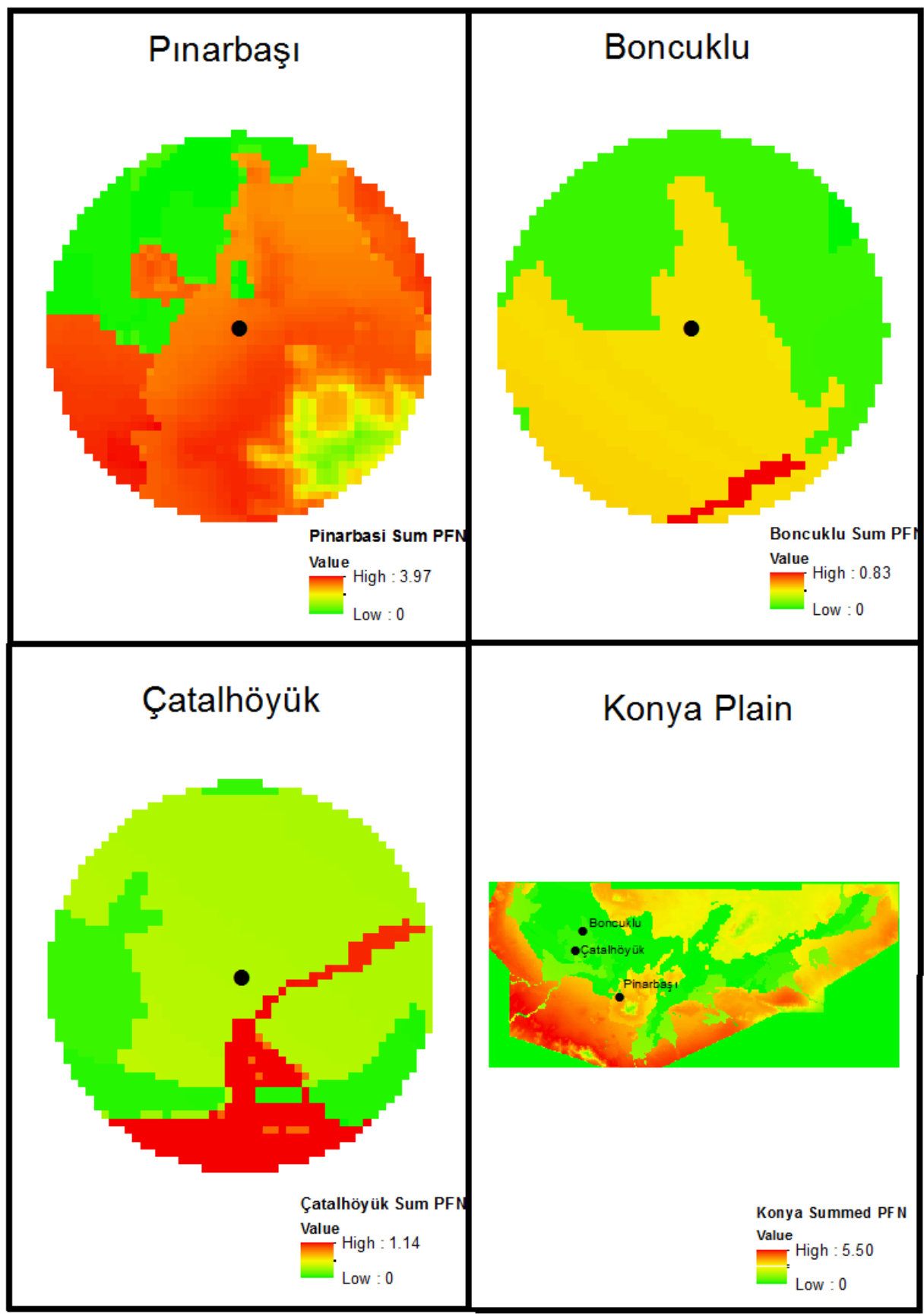

Figure 14: Summed PFN SCMs all plant species, $10 \mathrm{~km}$ radius of each site and for the entire 


\section{Boncuklu}

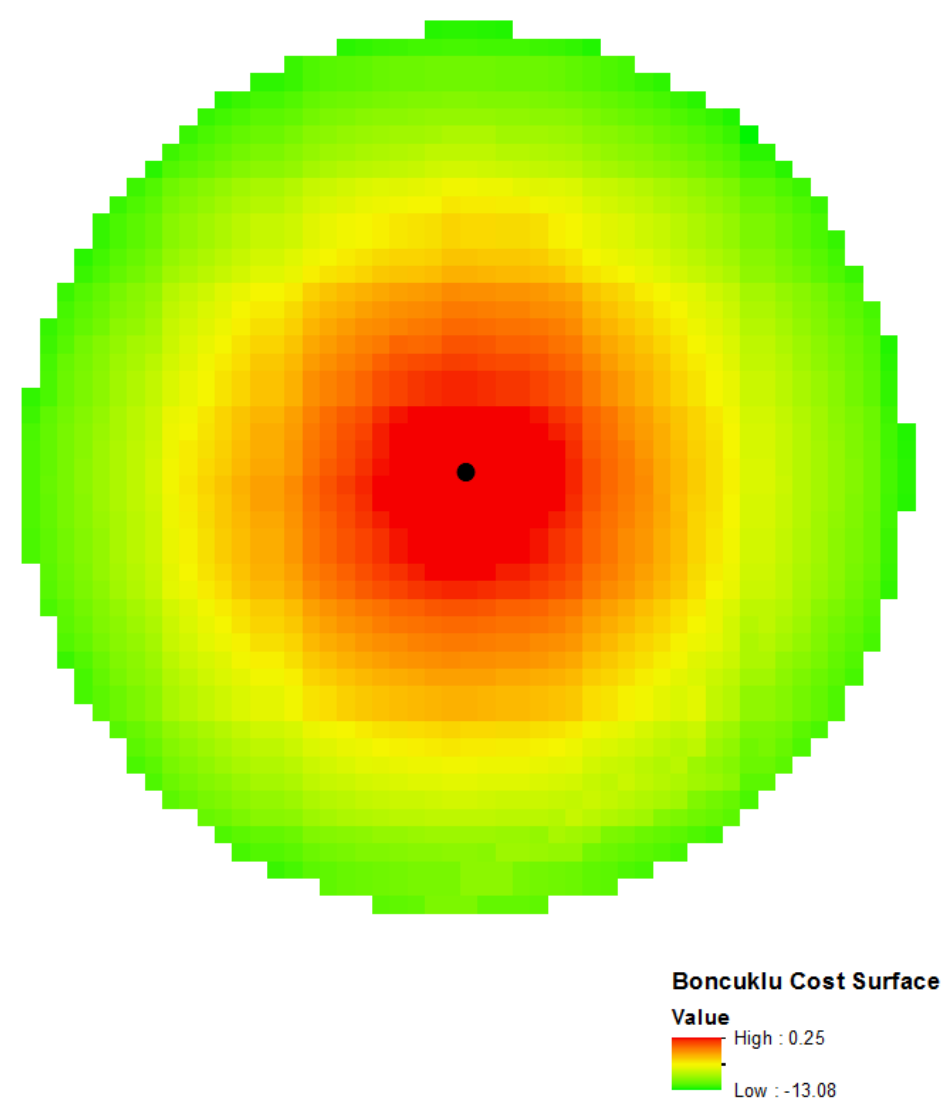

\section{Figure 15: Cost surface Boncuklu}

455

456

457

458

459

460

461

462

463

464

465

466

467

\section{Çatalhöyük}

The Çatalhöyük discounted PFN surface, like that of Boncuklu, is remarkably uniform, deviating very little from the simple distance from site surface. Again, it seems as if its inhabitants selected the site location in order to be centrally placed for non-agricultural resource procurement. However, given that (in contrast to Boncuklu and Pınarbaşı) the Çatalhöyük economy was predicated on mixed agropastoral production, the main criterion for 
468

469

470

471

472 site location almost certainly was the availability of land suitable for fixed-plot intensive horticulture in the immediate vicinity of the site that was least prone to the risk of annual flooding (Charles et al., 2014).

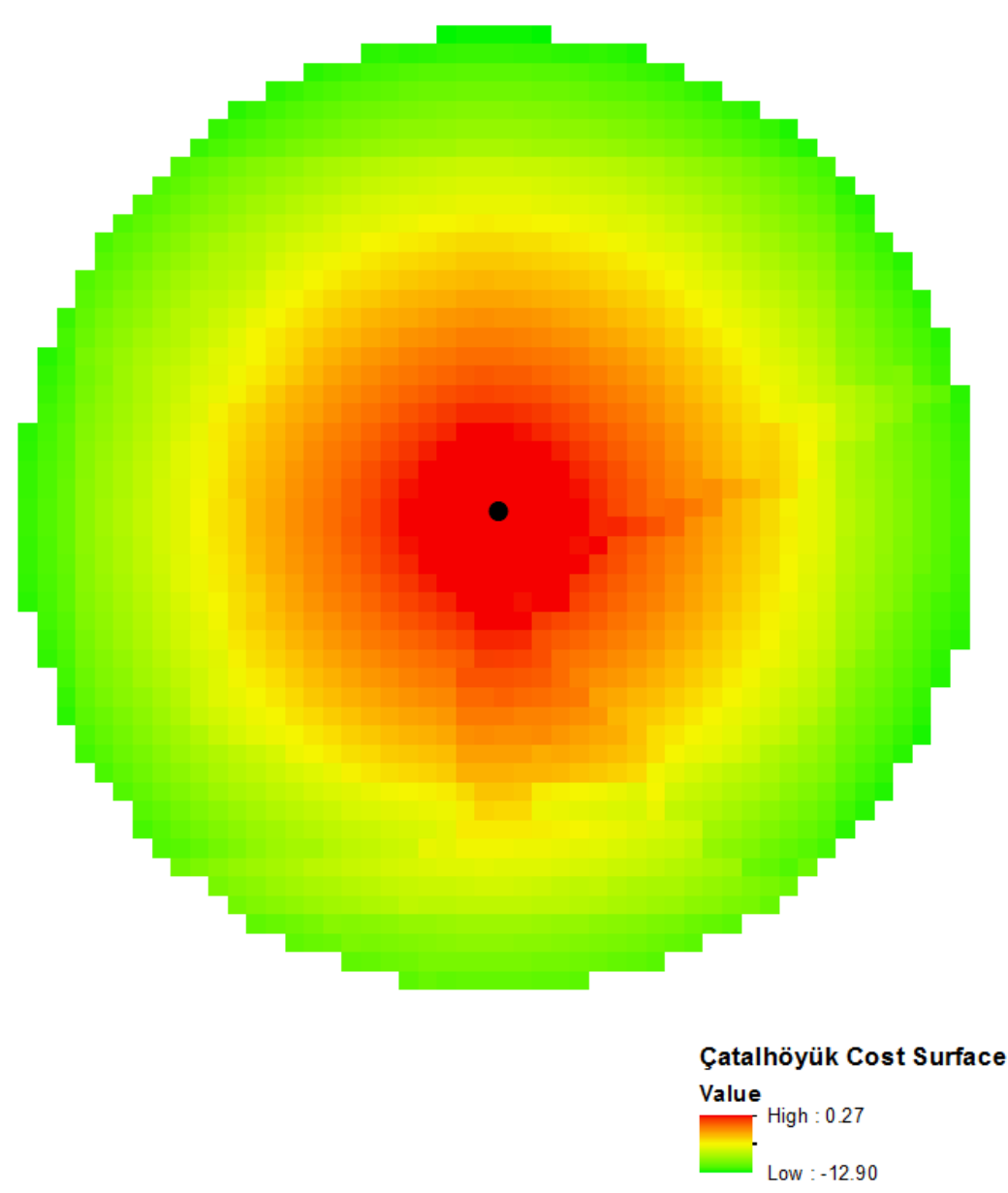

Figure 16: Çatalhöyük cost surface

473

474 Pınarbaşı

475 Like Boncuklu and Çatalhöyük, Pınarbaşı is centrally located within an area of resource 476 diversity. However, the cost-benefit surface is substantially less uniform than for these later 477 sites. This is due to the location of Pınarbaşı on the edge of the plain, on the foothills of 478 Karadağ. The more complex relief in this area introduces greater variation in the PFN. 


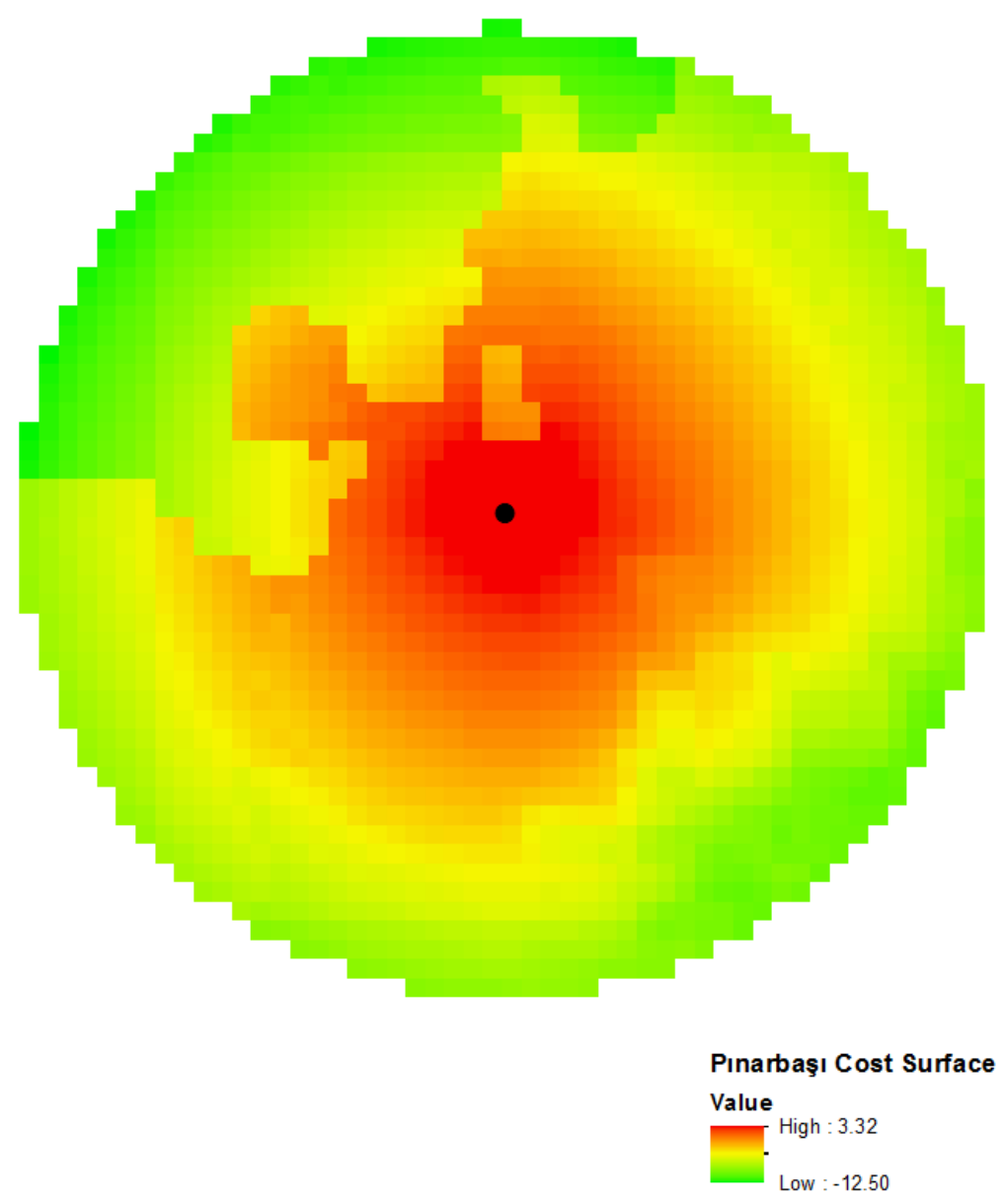

\section{Discussion}

Understanding resource choice by prehistoric communities in the early Holocene is of clear interest to archaeologists reconstructing the transition from foraging to farming, and economic decision-making during this critical period. The degree to which resource use inferred from archaeological assemblages corresponds to the predicted resource availability and distribution in the same geographical area and site territories can thus provide useful insights concerning the relative contribution of environmental availability and human agency in shaping prehistoric landscapes.

According to the SDM predictions described in the previous sections, the most common tree taxa found within 10km of early Holocene Pınarbaşı were Quercus, Celtis, Amygdalus and Juniperus. Asouti (2003) observed that Amygdalus, followed in much lower frequencies by Celtis and Pistacia, dominated the anthracological assemblage of late Neolithic $\left(7^{\text {th }}\right.$ millennium cal BC) Site B of Pınarbaşı, a pattern also verified by the work of Kabukcu on the 
495

496

497

498

499

500

501

502

503

504

505

506

507

508

509

510

511

512

513

514

515

516

517

518

519

520

521

522

523

$9^{\text {th }}$ millennium cal BC assemblage from Site A (Kabukcu, 2017a). Fairbairn et al. (2014) observed that almond (Amygdalus), terebinth (Pistacia) and hackberries (Celtis) dominate the non-wood archaeobotanical assemblage. By contrast, Quercus and Juniperus had a minimal presence in the anthracological remains, and they were not present at all in the non-wood archaeobotanical assemblage. This pattern is overall consistent with SDM predictions, with Amygdalus and Celtis being among the taxa predicted to have the greatest presence during the early-late Holocene around Pınarbaş1. Amygdalus seems to have been the preferred fuel wood and nut food source at Pınarbaşı throughout the prehistoric period.

The early Holocene $10 \mathrm{~km}$ radius of Boncuklu is predicted by the SDM as a landscape dominated by woodland taxa such as Amygdalus, Populus, Tamarix and Fraxinus. Asouti and Kabukcu (2014) and Kabukcu (2017a; forthcoming.) report the high presence of Salicaceae (Populus/Salix) in the Boncuklu anthracological assemblage. Amygdalus, Pistacia, Fraxinus, Celtis, Juniperus and Quercus appear in low frequencies but are relatively ubiquitous in the anthracological remains (Kabukcu, 2017a; forthcoming).

The non-wood archaeobotanical assemblage (Baird et al., 2012) has also indicated the presence of Amygdalus, Pistacia and Celtis. The partial disparities observed between the predicted SDM distributions of arboreal taxa and their presence and frequencies in the combined archaeobotanical and anthracological assemblages may be partly explained as the result of the existence of extensive marsh and wetland areas around Boncuklu during the prehistoric periods, something which could not be computed with the degree of spatial precision required by the SDM model that was by necessity reliant on modern soil type distributions. It is also likely that species such as Quercus and Juniperus were harvested and brought to the site from distant habitats in the surrounding upland zone, when their ecological preferences are taken into consideration (Asouti and Kabukcu, 2014). Taxa such as Amygdalus, Pistacia and the less abundant (in the anthracological assemblage) riparian Fraxinus and Ulmus may have had more restricted distributions in the Boncuklu 10km radius, because of the prevalence of marsh and submerged wetland habitats in the immediate vicinity of the site.

At Çatalhöyük the dominant tree species predicted by the SDM during the Holocene are Celtis, Amygdalus, Populus, Tamarix and Fraxinus. Celtis and Salicaceae (Populus/Salix) are among the most ubiquitous charcoal taxa identified at Çatalhöyük, although they are usually (if not always) present in relatively low frequencies throughout the long 
anthracological sequence sampled from the Neolithic East mound spanning 1000 years (cf. Asouti and Hather 2001; Asouti 2005, 2013; Asouti and Kabukcu 2014; Kabukcu, 2017a, b). However, other taxa that are ubiquitous and abundant in the anthracological assemblage such as Quercus, Juniperus and Ulmus, are not projected by the SDM to have been abundant in the environs of the site. Conversely, taxa that are projected by the SDM to have been abundant near the site (Tamarix, Fraxinus) have registered low frequencies in the anthracological assemblage. On this basis, the SDM appears to confirm the proposition that Quercus and Juniperus were preferentially selected as firewood and timber that were harvested in more distant localities to the south of the site (Asouti and Kabukcu, 2014). Furthermore, the disparity observed in the representation of specific components of the riparian vegetation (Ulmus, Fraxinus, Tamarix) between the SDM and the anthracological dataset is likely to pinpoint significant differences between the prehistoric and modern/historical distribution and ecology of riparian and wetland habitats around Çatalhöyük. Similar to the situation observed at Boncuklu, the early Holocene presence of now-extinct wetland and riparian micro-ecologies in the environs of Çatalhöyük is likely to be the principal reason why riparian taxa appear to be somewhat misrepresented in the maximum and mean pixel values graphs. However, it should be noted here that the Individual Species Surfaces produced by the SDM model discriminated very effectively between classic riparian arboreal taxa (e.g., Fraxinus, Ulmus) and those that can be ubiquitous in more typical wetland/marsh habitats as well (i.e., Tamarix, Salix/Populus) (see Supplementary data pp. 9-13). Salicaceae are also ubiquitous and abundant in the anthracological assemblage from Boncuklu, a site predicted to have occupied more typical wetland settings, while Ulmus and Fraxinus are better represented at Çatalhöyük that was situated in comparatively better drained alluvial settings.

The projected distribution of grassland taxa in the Konya plain is dominated by Triticum monococcum ssp. boeoticum (einkorn) followed by Hordeum vulgare ssp. spontaneum (barley). The SDM-predicted wide distribution of both taxa in early Holocene south-central Anatolia (and the corresponding predicted absence of the emmer wheat progenitor Triticum turgidum ssp. dicoccoides) thus provide strong independent verification of previous floristic surveys as summarized by Zohary et al. (2012). However, while Fairbairn et al. (2014) noted the presence of both einkorn and barley in the archaeobotanical assemblages from the $9^{\text {th }}$ millennium cal BC Site A at Pınarbaş1, this was limited to single grain finds that were intrusive from later levels. Einkorn and barley progenitors are also absent from the Boncuklu macrobotanical assemblage. The discrepancy between the SDM- 
predicted distribution of these taxa and their absence from the archaeobotanical assemblages appears therefore to be highly significant. The implication is that the wider Konya plain region was ecologically suitable for both wild einkorn and barley during the Holocene, yet neither taxon appears to have been targeted as a plant food resource by prehistoric communities. Moreover, their absence from the archaeobotanical assemblages cannot be attributed to inadequate sampling or preservation and retrieval biases; both sites have been intensively sampled for macrobotanical remains (Baird, 2012; Baird et al., 2012; Fairbairn et al., 2014). The SDM results therefore appear to confirm that $9^{\text {th }}$ millennium cal BC huntergatherer and cultivator-forager communities in the Konya plain were intentionally not harvesting and/or managing otherwise locally available cereal crop progenitor taxa. Other grass taxa that are predicted by SDM to have been relatively abundant in the landscape include Aegilops and Bolboschoenus. Bolboschoenus glaucus seeds have been identified at Pınarbaşı although Aegilops was absent (Fairbairn et al., 2014). At Boncuklu, Bolboschoenus was common, alongside reeds (Phragmites) and other wetland and steppe grass taxa. The presence of wetland and steppe grass taxa accords well with the locations of Pınarbaşı and Boncuklu in direct proximity to extensive wetland areas and steppe-wetland ecotones. While one should not altogether exclude the possibility that these taxa formed part of the subsistence repertoire at both sites, at the same time it is also possible that they may represent, to varying degrees, environmental "noise" in the archaeobotanical assemblages. The extensive use of reeds (Phragmites) as building, fuel and craft materials is also verified at both sites (Baird, 2012; Baird et al., 2012; Kabukcu, forthcoming). Although domesticated cereal crops have been attested at Boncuklu (Baird et al., 2012) very likely representing introductions from other regions, their low frequencies in the archaeobotanical assemblage suggest that they played a minor role in the diet of the inhabitants of the site. This is also confirmed by the study of human remains indicating the absence of dental carries at Boncuklu, which point to the minimal consumption of cereal grain by the site inhabitants (Pearson, forthcoming).

The apparent avoidance of cereal crop progenitor taxa as subsistence resources by the inhabitants of $9^{\text {th }}$ millennium cal BC Pınarbaşı and Boncuklu, despite the SDM-predicted wide availability of wild-type einkorn and barley in the local landscape, is not a phenomenon that is unique to south-central Anatolia. Comparable patterns of plant-derived subsistence practices are evidenced from several early Holocene habitation sites in eastern Anatolia, all of which are firmly located within the expected geographical ranges of crop progenitor species. 
593

594

595

596

597

598

599

600

601

602

603

604

605

606

607

608

609

610

611

612

613

614

615

616

617

618

619

620

621

622

623

624

Virtually no wheat or barley remains have been identified in Hasankeyf höyük, dated to the second half of the $10^{\text {th }}$ millennium cal BC; the Hasankeyf non-wood botanical assemblage is dominated by Amygdalus, Pistacia and Celtis alongside as yet indeterminate nut remains (Miyake et al., 2012; Tanno et al., 2016). Other sites in eastern Anatolia and northwest Zagros (e.g., Hallan Çemi, Demirköy, Qermez Dere, M'lefaat) and in the southern Levant (e.g., 'Iraq ed-Dubb, Netiv Hagdud) are also reported to contain large quantities of non-cereal seed taxa and nuts (Colledge, 2001; Savard et al., 2006; Willcox and Savard, 2011; Willcox, 2012). Another eastern Anatolian site, Körtik Tepe, has provided evidence for the harvesting of large to medium-seeded grasses, although (significantly) progenitor taxa formed a very small component of its archaeobotanical assemblage (Riehl et al., 2012) while comparable results regarding the relative under-representation of cereal crop progenitors compared to other wild grass taxa have also emerged from the long sequence sampled at the aceramic site of Chogha Golan in the central Zagros (Waide et al. 2018). Overall, this pattern suggests the existence of strong cultural preferences, likely determined by small-scale fluctuations in local microecologies alongside culturally mediated traditions of subsistence resource management strategies, which operated quite independently of plant resource availability in proximate and more distant site territories (Asouti 2017).

\section{Conclusion}

The application of the SDM method presented in this paper provides a powerful tool for the formal reconstruction of plant resource availability with a much higher degree of geographical and spatial precision when compared to traditional biogeographic reconstructions (e.g., Zohary, 1973) that have been widely applied to Southwest Asia (e.g., Zohary, 1973). SDM also provides a useful means for evaluating the degree of convergence and overlap between environmental availability and cultural choice filters affecting the composition of archaeobotanical assemblages. This is due to the unique capacity of SDM to generate independent palaeoenvironmental datasets that can be then directly compared to archaeological assemblages. Other distinctive advantages offered by SDM include its ease of application and thus its transferability to any world region, due to its reliance on open source data. The results produced by the application of SDM in the Konya plain of south-central Anatolia will be further refined and tested against the results of ongoing palaeoenvironmental analyses that are currently being prepared by the project team for publication. 


\section{Acknowledgements}

629 This research was funded by the Leverhulme Trust Standard Research Grant no. RPG 2012476 (Project title: "Unfamiliar landscapes: the transition from hunting-gathering to agriculture in the high-altitude plateau wetlands of Central Anatolia, Turkey"). We are grateful to Douglas Baird, Jessica Pearson, Louise Martin, and Andrew Fairbairn for useful discussions and advice. We are grateful also to Erich Fisher, and another anonymous reviewer for their helpful comments and suggestions on the earlier manuscript.

\section{Bibliography}

Asouti, E. 2003. Woodland vegetation and fuel exploitation at the prehistoric campsite of Pınarbaş1, south-central Anatolia, Turkey: the evidence from the wood charcoal macroremains. Journal of Archaeological Science 30:1185-1201.

641 Asouti, E. 2005. Woodland vegetation and the exploitation of fuel and timber at Neolithic

642 Çatalhöyük: report on the wood charcoal macro-remains. In Hodder, I. (ed.) Inhabiting

643 Çatalhöyük: Reports from the 1995-9 Seasons. McDonald Institute Monographs/British 644 Institute of Archaeology at Ankara, pp 213-258.

645 Asouti, E. 2006. Beyond the Pre-Pottery Neolithic B interaction sphere. Journal of World 646 Prehistory 20: 87-126.

647 Asouti, E. 2013. Woodland vegetation, firewood management and woodcrafts at Neolithic 648 Çatalhöyük. In Hodder, I. (ed.) Humans and landscapes of Çatalhöyük: reports from the 649 2000-2008 seasons. UCLA, Monographs of the Cotsen Institute of Archaeology, pp 129-161.

650 Asouti E. 2017. Human palaeoecology in Southwest Asia during the early Pre-Pottery 651 Neolithic (c. 9700-8500 cal BC): the plant story. In Benz M., Gebel H.G.K. and Watkins T. 652 (ed.s) Neolithic Corporate Identities. SENEPSE 20, ex oriente: Berlin, pp 21-53. Asouti, E., Austin, P. 2005. Reconstructing woodland vegetation and its exploitation by past societies, based on the analysis and interpretation of archaeological wood charcoal macroremains. Environmental Archaeology 10: 1-18. of Çatalhöyük East. Vegetation History and Archaeobotany. 10: 23-32. 
Asouti, E., Kabukcu, C. 2014. Holocene semi-arid oak woodland in the Irano-Anatolian region of Southwest Asia: natural or anthropogenic? Quaternary Science Reviews 90: 158182.

Bailey, H.P. 1960. A method of determining the warmth and temperateness of climate. Geografiska Annaler 42:1: 1-16.

Baird, D. 2012. Pınarbaşı: From Epi-Palaeolithic camp-site to sedentarising village in Central Anatolia. The Neolithic in Turkey, Vol. 3 Özdoğan, M., Başgelen, N. \& Kuniholm, P. (ed.s) Archaeology and Art Publications, Istanbul, pp 181-218.

Baird, D., Asouti, E., Astruc, L., Baysal, A., Baysal, E., Carruthers, D., Fairbairn, A., Kabukcu, C., Jenkins, Lorentz, K., Middleton, C., Pearson, J., Pirie, A. 2013. Juniper smoke, skulls and wolves' tails. The Epipalaeolithic of the Anatolian plateau in its South-west Asian context; insights from Pınarbaşı. Levant 45: 175-209.

Baird, D., Carruthers, D., Fairbairn, A., Pearson, J. 2011. Ritual in the landscape: evidence from Pınarbaşı in the seventh-millennium cal BC Konya Plain. Antiquity 85:328: 380-394.

Baird, D., Fairbairn, A., Martin, L. 2016. The animate house. The institutionalization of the household in Neolithic central Anatolia. World Archaeology DOI: $10.1080 / 00438243.2016 .1215259$

Baird, D., Fairbairn, A., Martin, L., Middleton, C. 2012b. The Boncuklu Project: The origins of sedentism, cultivation and herding in Central Anatolia. The Neolithic in Turkey, Vol. 3 Özdoğan, M., Başgelen, N. \& Kuniholm, P. (ed.s). Archaeology and Art Publications, Istanbul, pp 219-244

Bogaard, A., Charles, M., Livarda, A., Ergun, M., Filipovic, D., Jones, G. 2013. The archaeobotany of mid-later Neolithic occupation levels at Çatalhöyük. In I. Hodder (ed.), Humans and Landscapes of Çatalhöyük: Reports from the 2000-2008 seasons. Monographs of the Cotsen Institute of Archaeology, University of California at Los Angeles, Los Angeles, pp 93-128.

Bolte, A., Czajkowski, T., Kompa, T. 2007. The north-eastern distribution range of beech - a review. Forestry 80:4: 413-429.

Bottema, S., Woldring, H. 1984. Late Quaternary vegetation and climate of Southwestern Turkey. Part II. Palaeohistoria. 26: 123-149

Braconnot, P., Otto-Bliesner, B. Harrison, S., Joussaume, S., Peterchmitt, J.-Y., Abe-Ouchi, A., Crucifix, M., Driesschaert, E., Fichefet. Th., Hewitt, C. D., Kageyama, M., Kitoh, A., Laîné, A., Loutre, M.-F., Marti, O., Merkel, U., Ramstein, G., Valdes, P., Weber, S. L., Yu, Y., Zhao, Y. 2007. Results of PMIP2 coupled simulations of the Mid-Holocene and Last Glacial Maximum - Part 1: experiments and large-scale features. Climate of the Past 3: 261277.

Browicz, K., Zohary, D. 1996. The genus Amygdalus L. (Rosaceae): Species relationships, distribution and evolution under domestication. Genetic Resources and Crop Evolution 43: 229-247. 
Campbell, I.D. 1999. Quaternary pollen taphonomy: examples of differential redeposition and differential preservation. Palaeogeography, Palaeoclimatology, Palaeoecology. 149: 245-256.

Castro, A., Muñoz, A-R., Real, R. 2008. Modelling the spatial distribution of Tengmalm's owl Aegolius funereus in its Southwestern Palaeartic limit (NE Spain). Ardeola 55: 71-85.

Chabal, L., Fabre, L., Terral, J.-F.,Théry-Parisot, I. 1999. L'anthracologie. In BourquinMignot, C., Brochier, J.-E., Chabal, L., Crozat, S., Fabre, L., Guibal, F., Marinval, P., Richard, H., Terral, J.-F., Théry-Parisot, I. (ed.s) La Botanique. Errance, Paris, pp 43-104.

Chedaddi, R., Lamb, H.F., Guiot, J., van der Kaars, S. 1998. Holocene climatic change in Morocco: a quantitative reconstruction from pollen data. Climate Dynamics 14: 883-890

Colledge, S. 2001. Plant Exploitation on Epipalaeolithic and Early Neolithic sites in the Levant. British Archaeological Reports - Intern. Series 986. Archaeopress, Oxford.

Copeland, S. R., Cawthra, H. C., Fisher, E. C., Lee-Thorp, J. A., Cowling, R. M., le Roux, P. J., Marean, C. W. (2016). Strontium isotope investigation of ungulate movement patterns on the Pleistocene Paleo-Agulhas plain of the Greater Cape floristic region, South Africa. Quaternary Science Reviews 141, 65-84.

Davis, P.H., 1965. The Flora of Turkey and the East Aegean Islands. Edinburgh University Press, Edinburgh.

Davis, B.A.S., Brewer, S., Stevenson, A.C., Guiot, J., Data Contributors. 2003. The temperature of Europe during the Holocene reconstructed from pollen data. Quaternary Science Reviews 22: 1701-1716.

Elith, J., Leathwick, J.R. 2009. Species distribution models: ecological explanation, and prediction across space and time. Annual Review of Ecology Evolution and Systematics 40: 677-697.

Fairbairn, A., Jenkins, E., Baird, D., Jacobsen, G. 2014. $9^{\text {th }}$ millennium plant subsistence in the central Anatolian highlands: new evidence from Pinarbaş1, Karaman Province, central Anatolia. Journal of Archaeological Science 41, 801-812.

Farjon, A., Filer, D. 2013. An Atlas of the World's Conifers: An Analysis of Their Distribution, Biogeography, Diversity and Conservation Status. Brill, Leiden and Boston.

Franklin, J. 1995. Predictive vegetation mapping: geographic modelling of biospatial patterns in relation to environmental gradients. Progress in Physical Geography 19:4: 474-499.

Franklin, J., Potts, A.J., Fisher, E.C., Cowling, R.M., Marean, C.W. 2015. Paleodistribution modeling in archaeology and paleoanthropology. Quaternary Science Reviews 110: 1-14.

Global Biodiversity Information Facility (GBIF). www.gbif.org.

Göktürk, O.M., Fleitmann, D., Badertscher, S., Cheng, H., Edwards, R.L., Leuenberger, M., Fankhauser, A., Tüysüz, O., Kramers, J. 2011. Climate on the southern Black Sea coast during the Holocene: implication from the Sofular Cave record. Quaternary Science Reviews 30: 2433-2445. 
Guiot, J. 1990. Methodology of the last climatic cycle reconstruction in France from pollen data. Palaeogeography, Palaeoclimatology, Palaeoecology 80: 49-69

Hijmans, R. J., Cameron, S. E., Parra, J. L., Jones, P. G. and Jarvis, A. (2005), Very high resolution interpolated climate surfaces for global land areas. Int. J. Climatol., 25: 19651978. Data download: worldclim.org

Hodder, I. 2007. Çatalhöyük in the Context of the Middle Eastern Neolithic. Annual Review of Anthropology 36, 105-120.

Hodder, I., Orton, C. 1979. Spatial Analysis in Archaeology. Cambridge University Press, Cambridge

Hutchinson, G.E. 1957. Concluding Remarks. Cold Spring Harbor Symposium. Quantitative Biology 22, 415-427.

Jarvis A., H.I. Reuter, A. Nelson, E. Guevara. 2006. Hole-filled seamless SRTM data V3, International Centre for Tropical Agriculture (CIAT), available from http://srtm.csi.cgiar.org.

Joint Institute for the Study of the Atmosphere and Ocean. JISAO.

http://www.jisao.washington.edu

Jones, M.D., Roberts, C.N., Leng, M.J. 2007. Quantifying climatic change through the last glacial-interglacial transition based on lake isotope palaeohydrology from central Turkey. Quaternary Research 67: 463-473

Kabukcu, C. 2017a. Woodland vegetation history and human impacts in south-central Anatolia 16,000-6500 cal BP: Anthracological results from five prehistoric sites in the Konya plain. Quaternary Science Reviews 176: 85-100.

Kabukcu, C. 2017b. Identification of woodland management practices and tree growth conditions in archaeological fuel waste remains: a case study from the site of Çatalhöyük in central Anatolia, Turkey. Quaternary International. DOI: 10.1016/j.quaint.2017.03.017

Kabukcu, C. forthcoming. Woodland vegetation and fuel use in the Konya plain of central Anatolia during the $9^{\text {th }}$ millennium cal BC: anthracological remains from Boncuklu höyük. In Boncuklu; First Farmers in Central Anatolia and the Antecedents of Çatalhöyük. from Foragers to Farmers in Central Anatolia Volume 1, D. Baird and A. Fairbairn (ed.s). British Institute at Ankara, London.

Lee, R.B. 1969. Kung! Bushmen subsistence: An input-output analysis. In Contributions to Anthropology: Ecological Essays. Paper no. 6. Damas, D. (ed). National Museums of Canada Bulletin no 230, Ottawa.

de Meester, T. 1970. Soils of the Great Konya Basin. Agricultural University, Wageningen.

Miyake, Y., Maeda, O., Tanno, K., Hongo, H., Gündem C. Y. 2012. New excavations at Hasankeyf Höyük: A 10th millennium cal. BC site on the Upper Tigris, Southeast Anatolia. Neolithics 1:12: 3-7. 
Orland, I.J., Bar-Matthews, M., Ayalon, A., Matthews, A., Kozdon, R., Ushikubo, T., Valley, J.W. 2012. Seasonal resolution of Eastern Mediterranean climate change since 34 ka from a Soreq Cave speleothem. Geochimica et Cosmochimica Acta 89: 240-255.

Pearson, J. forthcoming. The first farmers of central Anatolia: a reconstruction and comparison of burial practice, diet and health at the Neolithic site of Boncuklu Höyük and beyond. In Boncuklu; First Farmers in Central Anatolia and the Antecedents of Çatalhöyük. from Foragers to Farmers in Central Anatolia Volume 1. Baird, D. and Fairbairn, A. (ed.s) British Institute at Ankara, London.

Picornell, G. L., Asouti, E., Martí, E. A. 2011. The ethnoarchaeology of firewood management in the Fang villages of Equatorial Guinea, central Africa: implications for the interpretation of wood fuel remains from archaeological sites. Journal of Anthropological Archaeology 30: 375-384.

Pross, J., Klotz, S. Mosbrugger, V. 2000. Reconstructing palaeotemperatures for the Early and Middle Pleistocene using the mutual climatic range method based on plant fossils. Quaternary Science Reviews 19: 1785-1799.

Riehl, S., Benz, M., Conard, N.J., Darabi, H., Deckers, K., Nashli, H.F., Zeidi-Kulehparchec, M. 2012. Plant use in three pre-Pottery Neolithic sites of the northern and eastern Fertile Crescent: a preliminary report. Vegetation History and Archaeobotany 21: 95-106.

Roberts, R., Reed, J.M., Leng, M.J., Kuzucuoglu, C. Fontugne, M., Bertaux, J., Woldring, H., Bottema, S. Black, S., Hunt, E., Karabiyikoğlu, M. 2001. The tempo of Holocene climatic change in the eastern Mediterranean region: new high-resolution crater-lake sediment data from central Turkey. The Holocene 11: 719-734.

Savard, M., Nesbitt, M., Jones, M.K. 2006. The role of wild grasses in subsistence and sedentism: new evidence from the northern Fertile Crescent. World Archaeology 38: 179196.

Shelford, V. E. 1931. Some concepts of Bioecology. Ecology 12: 455-467.

Surface-Evans, S., White, D. 2012. An introduction to the least cost analysis of social landscapes. In Surface-Evan, S., White, D. 2012 (ed.s) Least Cost Analysis of Social Landscapes: Archaeological Case Studies. University of Utah Press, Salt Lake City, pp 1-10.

Svenning, J-C., Fløjgaard, Marske, K.A., Nógues-Bravo, D. 2011. Applications of species distribution modelling to paleobiology. Quaternary Science Reviews 30: 2930-2947.

Tanno, K., Maeda, O., Miyake, Y. 2016. Plant remains from Hasankeyf Höyük: a new PPNA settlement in the upper Tigris valley. 17th Conference of the International Work Group for Palaeoethnobotany - Abstracts: Lectures and Posters, 38-39 (https://iwgp2016paris.sciencesconf.org/conference/iwgp2016paris/pages/livret_IWGP.pdf)

Tutin, T.G., Heywood, V.H., Burges, N.A., Valentine, D.H., Walters, S.M., Webb, D.A. 2010. Flora Europaea. Cambridge University Press, Cambridge

Vita-Finzi, C., Higgs, E. 1970. Prehistoric economy in the Mount Carmel area of Palestine: site catchment analysis. Proceedings of the Prehistoric Society 36: 1-37. 
815 Weide, A., Riehl, S., Zeidi, M., Conard, N.J. 2018. A systematic review of wild grass

816 exploitation in relation to emerging cereal cultivation throughout the Epipalaeolithic and

817 aceramic Neolithic of the Fertile Crescent. PLoS ONE 13:1: e0189811.

818 https://doi.org/10.1371/journal.pone.0189811

819 Wick, L., Lemcke, G., Sturm, M. 2003. Evidence of Lateglacial and Holocene climatic

820 change and human impact in eastern Anatolia: high-resolution pollen, charcoal, isotopic and

821 geochemical records from the laminated sediments of Lake Van, Turkey. The Holocene 13:

$822 \quad 665-675$

823 Willcox, G. 2012. Pre-domestic cultivation during the late Pleistocene and early Holocene in

824 the Northern Levant. In: P. Gepts, T.R. Famula, R.L. Bettinger, S.B. Brush, A.B. Damania,

825 P.E. McGuire, and C.O. Qualset (ed.s.), Biodiversity in Agriculture: Domestication,

826 Evolution, and Sustainability. Cambridge University Press, Cambridge, pp 92-109.

827 Willcox, G., Savard, M. 2011. Botanical evidence for the adoption of cultivation in southeast

828 Turkey. In: M. Özdoğan, N. Başgelen, and P. Kuniholm (ed.s.), The Neolithic in Turkey. New

829 Excavations \& New Research 2. The Euphrates Basin. Archaeology and Art Publications,

830 Istanbul, pp 267-280

831 Zohary D., Hopf M., Weiss E. 2012. Domestication of Plants in the Old World. $4^{\text {th }}$ edition.

832 Oxford University Press, Oxford

833 Zohary, M. 1973. Geobotanical Foundations of the Middle East. Gustav Fisher, Stuttgart. 